\title{
A Review of Recent Developments and Advanced Applications of High-Temperature Polymer Electrolyte Membranes for PEM Fuel Cells
}

\author{
Khadijeh Hooshyari ${ }^{1}$, Bahman Amini Horri ${ }^{2, *(D)}$, Hamid Abdoli ${ }^{3}$ (D) Mohsen Fallah Vostakola ${ }^{4}$ (D), \\ Parvaneh Kakavand ${ }^{5}$ and Parisa Salarizadeh ${ }^{6}$
}

1 Department of Applied Chemistry, Faculty of Chemistry, Urmia University, Urmia 57561-51818, Iran; kh.hooshyari@urmia.ac.ir

2 Department of Chemical and Process Engineering, University of Surrey, Surrey GU2 7XH, UK

3 Department of Renewable Energy, Niroo Research Institute, Tehran 14686-13113, Iran; hamidabdoli@yahoo.com

4 School of Metallurgy and Materials Engineering, Iran University of Science and Technology (IUST), Narmak, Tehran 16846-13114, Iran; m_fallah69@metaleng.iust.ac.ir

5 Department of Chemistry, Amirkabir University of Technology, Tehran 15875-4413, Iran; p.kakavand@ak.ac.ir

6 High-Temperature Fuel Cell Research Department, Vali-e-Asr University of Rafsanjan, Rafsanjan 77188-97111, Iran; s.Salarizadeh@vau.ac.ir

* Correspondence: b.aminihorri@surrey.ac.uk; Tel.: +44-1483-689-846

check for updates

Citation: Hooshyari, K.; Amini Horri, B.; Abdoli, H.; Fallah Vostakola, M.; Kakavand, P.; Salarizadeh, P. A Review of Recent Developments and Advanced Applications of HighTemperature Polymer Electrolyte Membranes for PEM Fuel Cells. Energies 2021, 14, 5440. https:// doi.org/10.3390/en14175440

Academic Editor: Felix Barreras

Received: 5 August 2021

Accepted: 26 August 2021

Published: 1 September 2021

Publisher's Note: MDPI stays neutral with regard to jurisdictional claims in published maps and institutional affiliations.

Copyright: (c) 2021 by the authors. Licensee MDPI, Basel, Switzerland. This article is an open access article distributed under the terms and conditions of the Creative Commons Attribution (CC BY) license (https:// creativecommons.org/licenses/by/ $4.0 /)$.

\begin{abstract}
This review summarizes the current status, operating principles, and recent advances in high-temperature polymer electrolyte membranes (HT-PEMs), with a particular focus on the recent developments, technical challenges, and commercial prospects of the HT-PEM fuel cells. A detailed review of the most recent research activities has been covered by this work, with a major focus on the state-of-the-art concepts describing the proton conductivity and degradation mechanisms of HT-PEMs. In addition, the fuel cell performance and the lifetime of HT-PEM fuel cells as a function of operating conditions have been discussed. In addition, the review highlights the important outcomes found in the recent literature about the HT-PEM fuel cell. The main objectives of this review paper are as follows: (1) the latest development of the HT-PEMs, primarily based on polybenzimidazole membranes and (2) the latest development of the fuel cell performance and the lifetime of the HT-PEMs.
\end{abstract}

Keywords: polymer electrolyte membranes; high temperature; proton conductivity; polybenzimidazole; fuel cell performance

\section{Introduction}

Sufficient access to clean energy sources is one of the ongoing key challenges for global development that directly impacts industrial development, economic growth, and human well-being. Historically, the energy sector is widely dominated based on fossil fuels (such as petroleum fuels, natural gas, coal, etc.), which are the primary sources of carbon dioxide $\left(\mathrm{CO}_{2}\right)$ and other greenhouse gases emissions in the environment. This has fundamentally driven a global climate change that has been accelerated over the past few decades and hence needs significant and immediate actions in order to alter both the energy sources and energy conversion techniques. There is a growing movement by the research and manufacturing communities to alleviate the impact of the petroleum-based economy by developing clean energy sources for implementing an alternative hydrogenbased economy [1-3]. Developing new clean energy supplies requires abundant access to sustainable energy sources. Thus, the energy storage systems such as lithium-ion batteries, redox flow batteries, and other fuel-cell-based power-to-gas technologies should be well integrated side by side, while developing the new capabilities of renewable energy 
sources. The lithium-ion battery is one of the most promising energy storage candidates in the portable and auxiliary device markets due to its high power density, environmental friendliness, and long service life [4]. By contrast, redox flow (cell) batteries can be used for large-scale energy storage applications. Their unique design leads to a higher power-tocapacity ratio from about 1:10 to $1: 4$. However, their toxicity, corrosivity, and high costs of the electrolyte solutions as well as low charge/discharge rate (1-10 h) and relatively low energy density have limited their applications [5-7]. Given the current environmental challenges associated with fossil fuels, fuel cell technology has been introduced as a promising, cleaner, high energy density, and more efficient power generation system [2,8,9]. The first fuel cell to operate with hydrogen and oxygen was developed about 150 years ago by Sir William Grove and was then further studied by developing many other sorts of fuel cells within the 19th century [8,10]. Lately, polymer electrolyte membrane (PEM) fuel cells, which directly convert the chemical energy of hydrogen into electrical energy, were predominantly developed as the most common commercial fuel cell [11,12]. Hydrogen gas (as a fuel with the highest energy density) and oxygen (usually taken from the air) are being used in a PEM fuel cells over the surface of electrodes to produce water through a few electrochemical reactions that are associated with the electrical power generation [13]. Structurally, a PEM fuel cell is comprised of an electrolyte layer at the middle integrated with anode and cathode electrodes over that, along with a current collector layer on top of each side of the cell. The polymer electrolyte membrane is a protonic conductor and electronic insulator sandwiched between a pair of electrodes [14]. The PEM fuel cells are classified into two important types, including low-temperature PEM (LT-PEM) and high-temperature PEM (HT-PEM) fuel cells [15,16]. Direct ethanol fuel cells [17] and direct methanol fuel cells [18] are the subset of PEM fuel cells. Figure 1 summarizes the trend of the total publication records (yearly and cumulative) in "HT-PEM fuel cell" according to the "Web of Science" indexing database till September 2020. This histogram shows gradual growth of the number of publications starting in 2003 and reaches about 1100 papers in 2015 , followed by an almost linear decline in the past few years.

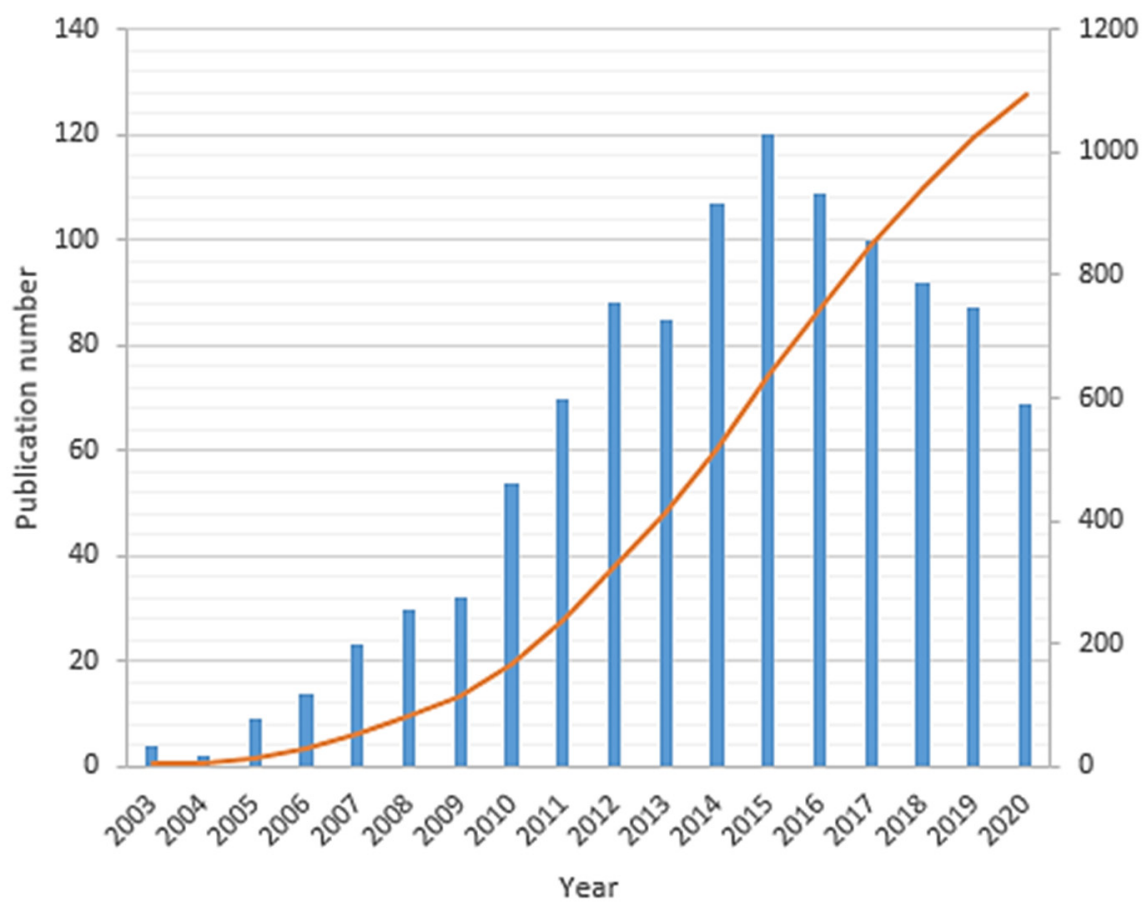

Figure 1. The number of yearly and total publications on HT-PEM fuel cell research field from the WoS indexing database.

VOSviewer application $[19,20]$ (a social network analysis software) was used to qualitatively analyse the network of the published records in the HT-PEM subject within the last 
couple of decades. The main keywords that have received at least ten occurrences were identified and used to map a connection network model represented in Figure 2. This map reveals the main keywords and categorises them in accordance with their co-occurrence. The size of each node represents the relative importance of a keyword in the literature, and the distance among keywords implies the probability of co-occurrence and relatedness. According to this figure, the most frequent keywords regarding HT-PEMFCs are related to their performance, conductivity, polybenzimidazole (PBI) membranes, acid, composite/nanocomposite membranes, and cell degradation/durability. Many researchers have focused on the performance of cell performance and improving cell conductivity. PBI does not have proton conductivity without acid doping; acid-doped PBI membranes showed the promising electrochemical performance to be used in high-temperature applications [21]. Another practical approach for improving cell performance is the fabrication of polymer composite/nanocomposite membranes which can improve proton conductivity, water uptake/retention, thermal/chemical durability, mechanical strength, etc. [22-24].

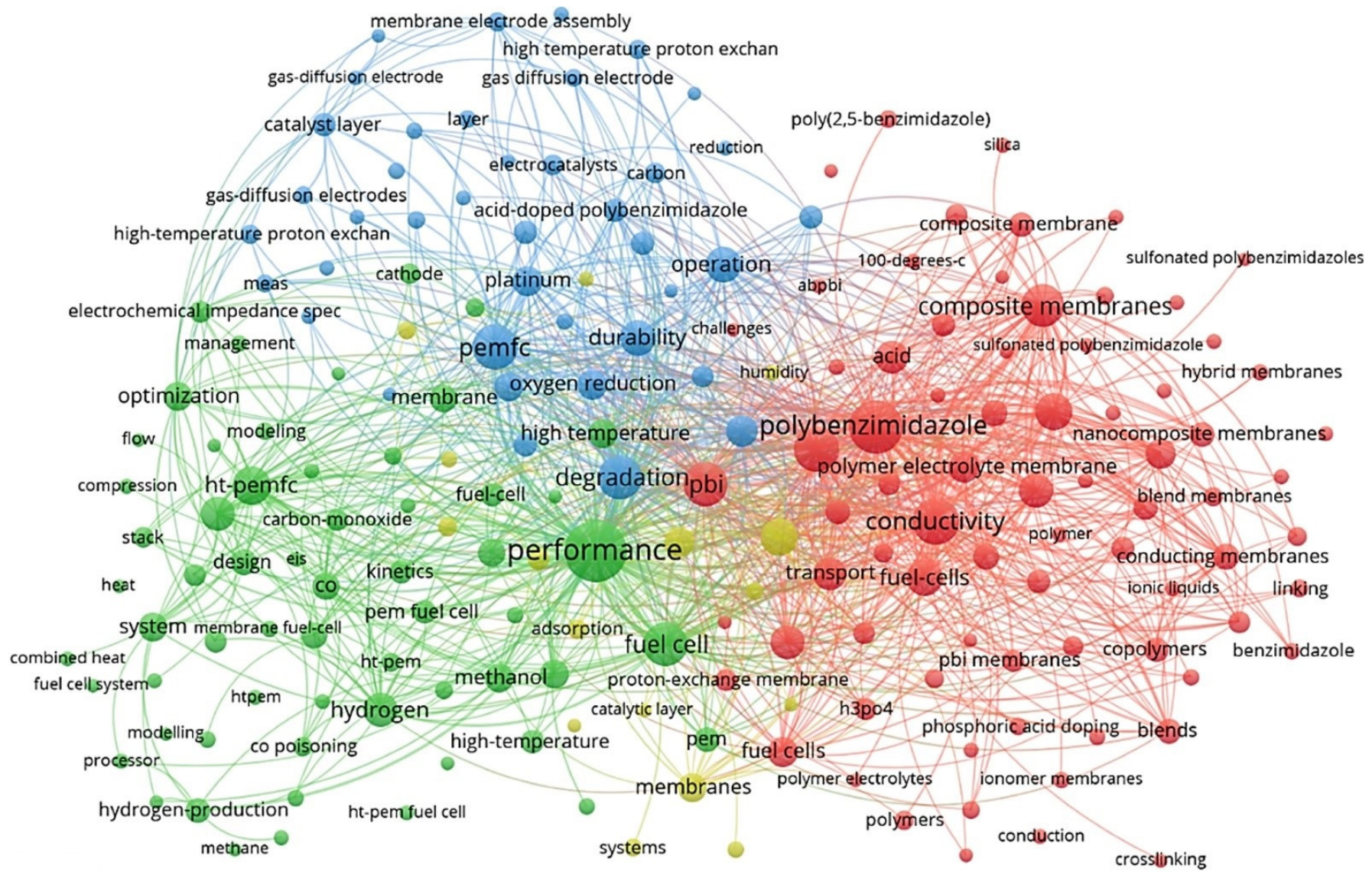

Figure 2. The overview of main keyword clusters in HT-PEM fuel cell research field, representing the main subfield.

\section{Desirable Properties of PEMs}

The PEM is the heart of the membrane electrode assemblies (MEAs), which are used for the fabrication of the PEM fuel cell stacks [25]. The PEM has a vital role in a fuel cell assembly by performing various functions such as being a carrier path for proton transport from the anode to the cathode side, a dense separation layer to block the mixing of the reactants, and an electric insulation layer between the anode and cathode. Many studies in the past few years have reported the enhancement of various functions of PEMs [26-30]. One of the key objectives for the PEMs' development is to reduce the cells' total fabrication cost and improve their electrochemical performance and durability [31,32]. A desirable costeffective PEM should exhibit an acceptable thermochemical and thermomechanical stability, 
low permeability to fuel and oxidants, high proton conductivity, high compatibility with the electrodes in an MEA, long durability, and a low electro-osmotic drag coefficient $[33,34]$.

\section{Improving Proton Conductivity of the Membranes}

\subsection{Effects of Dopants and Additives}

Several dopants have been used to improve the proton conductivity of PEMs, especially PBI. The proton conductivity of PBI is very low, and it requires the incorporation of dopants, additives, etc. [35]. Full or partial protonation or deprotonation of the polymers happens depending on the concentration and chemical nature of the dopant [36]. PBI is an amphoteric compound and has both proton acceptor and proton donor sites [37]. A wide variety of acids and bases, such as $\mathrm{H}_{2} \mathrm{SO}_{4}$ [38], $\mathrm{H}_{3} \mathrm{PO}_{4}$ [39], $\mathrm{HBr}$ [40], $\mathrm{NaOH}$ [41], $\mathrm{KOH}$ [42], etc., have been used as dopants. Compared to the low-temperature cells, HT-PEMs require high-boiling dopants which can operate at elevated operational temperatures [43]. Dopant concentration is a key parameter in improving proton conductivity, however, up to a certain amount. Excessive doping may deteriorate the conductivity. For example, acid doping with a high concentration $\left(>11\right.$ mol. $\mathrm{L}^{-1}$ ) decreases the proton conductivity [36].

Sulfuric acid is an excellent dopant for PEMs; however, its high vapour pressure is a major drawback [36]. Phosphoric acid (PA) has been known to be the most promising additive/dopant for improving the proton conductivity of PBI because of its high thermal stability, high proton conductivity, low vapour pressure, and very low water content $[36,44]$. Although PA is an excellent proton conductor at high temperatures, which is about $0.8 \mathrm{~S} . \mathrm{cm}^{-1}$ at $200{ }^{\circ} \mathrm{C}$, its conductivity decreases after incorporating in a polymer matrix [45]. The main drawbacks associated with PA are membrane degradation and catalyst poisoning due to the harsh operating conditions and unfavourable electrochemical reactions as well as acid leaching. Thereby, the highest performance can be achieved by optimising the acid-doping level (ADL) or other strategies such as covalent crosslinking or making composite PEMs [28]. Depending on the ADL, PA can be classified into two general groups: "bonded acid" and "free acid". When the acid concentration increases from 2 to $11 \mathrm{M}$, the $\mathrm{H}^{+}$hopping between the $\mathrm{N}-\mathrm{H}$ site and the $\mathrm{PO}_{4}^{3-}$ anions results in proton migration [46]. In this case, the "bonded acid" remains almost constant, but the amount of "free acid" increases and consequently leads to higher proton conductivities. Therefore, the key parameter in determining the proton conductivity of PA-doped membranes is the presence of "free acid" [47]. Mader et al. [48] fabricated PA-doped PBI membranes with high proton conductivity $\left(>10^{-1} \mathrm{~S} . \mathrm{cm}^{-1}\right.$ at above $\left.100^{\circ} \mathrm{C}\right)$ and excellent mechanical strength. The PA loading level was about 22-55 PA/PBI, and the final solid content was about 3.5-4.0 wt.\% and IV's > $1.0 \mathrm{dL} . \mathrm{g}^{-1}$. Li et al. [49] also investigated the effect of PA doping on the performance of HT-PEMs. In order to overcome the deterioration of mechanical properties caused by the "plasticizing effect" of the acid doping, they fabricated a highly acidophilic imidazole-rich crosslinked network with " $\mathrm{A}_{2} \mathrm{~B}_{2}$-type" structure and an excellent "antiplasticizing" effect. The high reactivity of this structure enabled higher ADL, proton conductivity, mechanical/dimensional stability, and cell performance. Proton conductivity and peak power density of the PBI with a $30 \%$ degree of crosslinking were $2.53 \times 10^{-1} \mathrm{~S} . \mathrm{cm}^{-1}$ at $200{ }^{\circ} \mathrm{C}$ and $533 \mathrm{~mW} . \mathrm{cm}^{-2}$ at $160{ }^{\circ} \mathrm{C}$.

Doping the PBI matrix with the alkali cations can also increase the ionic conductivity of the resulting membrane. The ionic conductivity of the alkali-doped PBI membranes depends on the basicity of the resulting compounds. For example, the ionic conductivity of $\mathrm{PBI} / \mathrm{LiOH}$ and $\mathrm{PBI} / \mathrm{KOH}$ has been reported to be about $4 \times 10^{-5} \mathrm{~S} . \mathrm{cm}^{-1}$ and $6.5 \times 10^{-2}{\mathrm{~S} . \mathrm{cm}^{-1}}^{-1}$, respectively [50]. Compared to the basic compounds, solid inorganic proton-conducting molecules such as heteropolyacids (HPAs) showed higher proton conductivity. HPAs, such as $\mathrm{H}_{3} \mathrm{PMo}_{12} \mathrm{O}_{40} \cdot 29 \mathrm{H}_{2} \mathrm{O}\left(\mathrm{PMo}_{12} \cdot 30 \mathrm{H}_{2} \mathrm{O}\right)$, are highly hygroscopic materials with high proton conductivity $\left(9.1 \times 10^{-2} \mathrm{~S} . \mathrm{cm}^{-1}\right.$ for $\left.\mathrm{PMo}_{12} \cdot 30 \mathrm{H}_{2} \mathrm{O}\right)$ and excellent thermal stability [51]. High proton conductivity of about $10^{-2}$ and $10^{-1} \mathrm{~S} . \mathrm{cm}^{-1}$ at 25 and $100{ }^{\circ} \mathrm{C}$, respectively, has been reported by Zaidi et al. [52] for the HPA-SPEEK composite membranes. Solid acids such as zirconium hydrogen phosphate, phosphotungstic 
(PWA), and silicotungstic (SiWA) acids have also been investigated for their high proton conductivity. It has been reported that the proton conductivity of heteropolyacids such as PWA and SiWA increases with increasing RH. However, because not all the protons are available at elevated temperatures, their proton conductivity is generally low [35,51].

Inorganic compounds have also been used as dopants in PEMs [53,54]. Park et al. [53] investigated the effect of the $\mathrm{Si}$ and $\mathrm{Zr}$ cations on the performance of Nafion membranes. They reported that the water uptake of Si-doped membrane was lower than the recast Nafion and commercial Nafion 112, while the water uptake of Zr-doped Nafion reached about $39 \%$. The proton conductivity of the $\mathrm{Zr}$-doped sample at $80{ }^{\circ} \mathrm{C}$ and $\mathrm{RH}=90 \%$ was about $10^{-1} \mathrm{~S} . \mathrm{cm}^{-1}$, which was higher than those of recast Nafion, Nafion 112, and Si-doped membrane $\left(\sim 7 \times 10^{-2} \mathrm{~S} . \mathrm{cm}^{-1}\right)$. They also compared the proton conductivity of the membranes at $120{ }^{\circ} \mathrm{C}$ and $\mathrm{RH}=50 \%$ and found that the proton conductivity of the recast Nafion and commercial Nafion 112 was about $1.75 \times 10^{-2}{\mathrm{~S} . \mathrm{cm}^{-1}}^{-}$. The proton conductivity of Si-doped, $\mathrm{Zr}$-doped, and ( $\mathrm{Si} / \mathrm{Zr}$ ) dual-doped membranes (with $\mathrm{Si}$ to $\mathrm{Zr}$ ration of 2) was about $2.4 \times 10^{-2}, 2.6 \times 10^{-2}$, and $3 \times 10^{-2}{\mathrm{~S} . \mathrm{cm}^{-1}}^{\text {, respectively. }}$

In general, PEMs have low proton conductivity, and in order to improve their cell performance, dopants addition is a practical approach. ADL is a critical issue that has a significant effect on cell performance. Optimized doping can improve proton conductivity; however, excessive doping can deteriorate cell performance as well as its lifetime and mechanical properties.

\subsection{Effect of Molecular Weight}

Asensio et al. [51] reported that molecular weight (MW) has a vital role in improving mechanical strength. In order to prepare a highly conductive membrane, the polymer matrix with a comparably higher molecular weight should be applied. However, such an approach may not have a significant impact on the resulting proton conductivity of PEMs. Berber et al. [55] synthesized polybenzimidazole (ph-PBI) polymers with different MWs and reported that the high MW membrane (119 KDa) exhibited the most increased chemical stability, mechanical strength, and cell performance. In another attempt, Berber [56] fabricated ABPBI membranes with different MWs (20-113 KDa) and investigated the physicochemical properties, acid loading level, dopant retention capabilities, chemical stability, proton conductivity, and IEC of them. They reported that the high MW ABPBI showed the highest acid retention capability because of the chain entanglement, which resulted in trapping more PA molecules. High MW ABPBI showed higher chemical stability (9 wt.\% weight loss after seven days in the Fenton reagent at $65^{\circ} \mathrm{C}$ ). The mechanism of proton conductivity was found to follow the "Grotthuss" mechanism, and the high MW sample possessed the highest proton conductivity among the samples (about $8 \times 10^{-3}{\mathrm{~S} . \mathrm{cm}^{-1}}^{-1}$ at $140^{\circ} \mathrm{C}$ ). The IEC value of the high MW ABPBI was found to be increased by order of magnitude compared to the low MW one. Similar observations were reported by other researchers $[30,57,58]$.

\subsection{Polymer Composites}

An effective approach to improving the proton conductivity of PEMs is to incorporate some additional components. Composite membranes showed promising potential to be used as HT-PEMFCs. Composite materials consist of two or more constituents with different chemical, mechanical, or physical properties [59]. Composite membranes have widely been used in PEMFCs such as PTFE/Nafion [59], metal-oxiderecast/Nafion [60], copper phthalocyanine tetrasulfonic acid tetrasodium salt (CuT$\mathrm{SPc}$ )/Nafion [61], calcium titanate/PBI [62], $\mathrm{PBI}-\mathrm{SiO}_{2}$ [63], $\mathrm{Nafion}{ }^{\circledR} / \mathrm{SiO}_{2}$ [64], polyvinylidene fluoride (PVDF)/Nafion [65], Nafion/polyaniline [66], PBI/graphene oxide [24], etc. Fillers can provide additional chemical resistance, mechanical strength, and proton conductivity. Hydrophilic fillers improve membrane water uptake, and thereby, they can be used in low RH environments [59]. Inorganic fillers have high mechanical strength, thermal stability, and water-absorbing capacity and can be used in low $\mathrm{RH}$ and/or at elevated 
temperatures. The change in $\mathrm{H}_{2}$ crossover and proton conductivity at different operating conditions with/without filler in Nafion is illustrated in Figure 3. As shown in Figure 3a, the channels within the membrane are fully saturated with water and the mechanisms for proton conduction can be either "Grotthus" or diffusion. In this case, open-circuit voltage $(\mathrm{OCV})$ can be reduced due to the molecular $\mathrm{H}_{2}$ passing through the membrane $\left(\mathrm{H}_{2}\right.$ crossover). At higher temperatures (Figure 3b), water begins evaporation and results in the shrinkage of the channels and decreasing proton conductivity. On the other hand, $\mathrm{H}_{2}$ crossover improves at elevated temperatures. Adding filler to the composite (Figure 3c) can decrease $\mathrm{H}_{2}$ crossover and increase $\mathrm{H}_{2}$ path to migrate from anode to cathode [59].
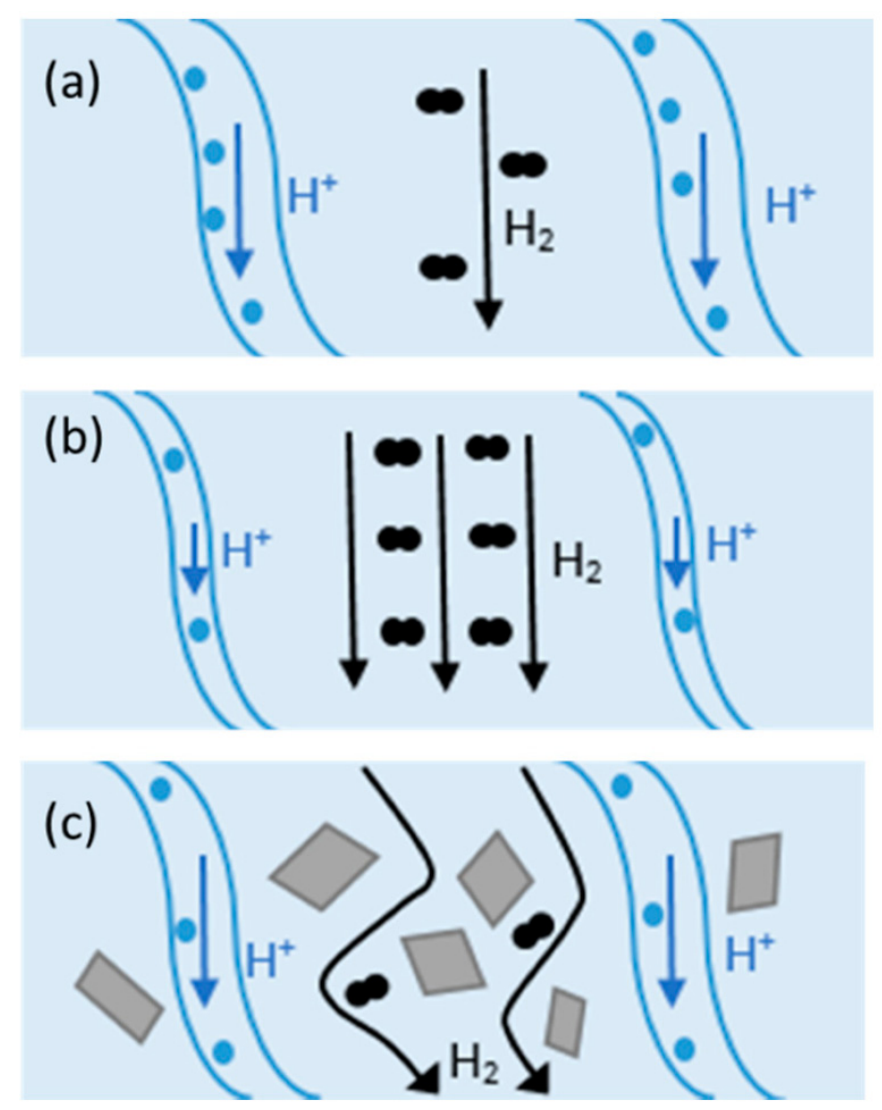

Figure 3. Proton and $\mathrm{H}_{2}$ transport at (a) $80{ }^{\circ} \mathrm{C}$, (b) at elevated temperatures, and (c) in Nafion composite at high temperatures. Reproduced from [59], MDPI: 2020.

Different types of fillers have been used for improving the PEMs performance. Ceria is a filler that can diminish membrane degradation by acting as a regenerative free-radical scavenger [67]. Hydrophilic fillers can absorb a large quantity of water and improve proton conductivity and alleviate the unfavourable effect of high temperatures [60]. Although silica nanoparticles are hydrophobic, it has been reported that they do not have any negative effect on membrane water uptake [68]. Dispersion of sulphonated zirconia in the Nafion matrix can also improve the proton conductivity by functionalizing the $\mathrm{Zr}$ with sulphonic groups. Proton conductivity of about $3 \times 10^{-3} \mathrm{~S} . \mathrm{cm}^{-1}$ at $120^{\circ} \mathrm{C}$ and under anhydrous conditions has been reported for this PEM composite [69]. Although increasing water uptake is favourable, excessive water uptake may negatively affect performance [70]. Graphene oxide is a hydrophilic material with lots of oxygen-containing functional groups and has recently been used as fillers in PEMFCs [71]. It has been reported that graphene oxide (GO) composite membranes can extend the operating temperature because they can retain more water and increase the proton conductivity [24,59].

Mixed-matrix membranes (MMMs) are a class of membranes comprised of a solid phase uniformly distributed in a polymer matrix. MMMs benefit from the advantages of the 
polymer membrane (high flexibility and ion exchange capacity) and inorganic constituents (high thermal and mechanical properties, water uptake, and proton conductivity) [72]. Among the inorganic materials, metal-organic frameworks such as $\mathrm{Fe}, \mathrm{Cr}, \mathrm{Al}$, and $\mathrm{Zr}$ have high specific surface areas and offer higher proton conductivity. These MOFs can improve proton conductivity by defect engineering, postsynthetic modification, and impregnation with acidic molecules [73]. Amongst various forms of the applied MOFs, chromium terephthalate such as MIL-101(Cr) (MIL stands for Materials of Institute Lavoisier) with the chemical formula of $\left\{\mathrm{Cr}_{3} \mathrm{~F}\left(\mathrm{H}_{2} \mathrm{O}\right)_{2} \mathrm{O}(\mathrm{BDC})_{3} \cdot \mathrm{nH}_{2} \mathrm{O}\right\}$ (n 25; 1,4-benzenedicarboxylate (BDC) showed higher conductivity than the other types. This material can easily be functionalized with excellent chemical/hydrothermal stability and is strongly resistant against moisture and organic molecules [74]. High proton conductivity of about $4.1 \times 10^{-2} \mathrm{~S}^{-c 006 D^{-1}}$ at $160{ }^{\circ} \mathrm{C}$ and $\mathrm{RH}=0 \%$ has been reported by Anahidzade et al. [75], who fabricated MIL-101 (Cr) by hydrothermal method followed by functionalizing it via the postgrafting route. However, restricted proton transportation caused by the grain boundary of MOFs resulted in decreasing the proton conductivity [76]. To overcome this issue, MOFs hybridization with other polymers can alleviate the low proton conductivity [77]. UiO-series (UiO stands for the University of Oslo) MOFs are another class of MOFs that has attracted considerable interest because of their high energy conversion rate and low operating temperatures. These materials mainly contain $\mathrm{Zr}$ and have excellent chemical and thermal stability due to the highly oxyphilic $\mathrm{Zr}$ (IV) atoms [78,79]. In this context, Rao et al. [78] fabricated Nafion/GO@UiO-

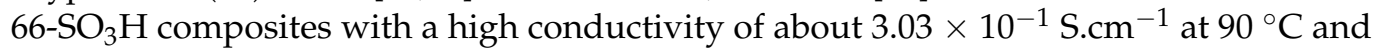
$\mathrm{RH}=95 \%$. They reported that consecutive proton transfer channels were constructed within the PEM composite due to the suitable interconnection of MOF grains and the tethering effect of GO surfaces. It has been reported that $\mathrm{UiO}-66$ possesses a very poor proton conductivity of about $7 \times 10^{-6}$. However, sulphonated $\mathrm{UiO}-66\left(\mathrm{UiO}-66-\mathrm{SO}_{3} \mathrm{H}\right)$ has super protonic conductivity (four orders of magnitude greater than the UiO-66) [80-82]. The synergic effect between $\mathrm{UiO}-66-\mathrm{SO}_{3} \mathrm{H}$ and $\mathrm{Uio}-66-\mathrm{NH}_{2}$ was found to have a great effect on the proton conductivity of the composite [83]. Other types of MOFs such as zeolite imidazolate frameworks (ZIFs) [84], a chiral 2-D MOF named "MOF 1" [85], which combined protic ionic liquids (PILs) with porous MOFs [86], etc., have also been investigated. Overall, MOFs-modified PEMFCs have shown promising electrochemical performance at high temperatures and anhydrous conditions. MIL class can promote proton conductivity using the abundant hydroxyl groups. The UiO class possesses a high-density spatial structure with strong chemical stability. Selecting the appropriate composite, suitable dispersion condition, and the MOF concentration is the most critical factor affecting the composites' conductivity and physiochemical/thermal stability.

\subsection{Other Important Parameters}

In addition to the abovementioned parameters, other factors such as membrane morphology and water uptake are of great importance. Although high water uptake improves proton conductivity, excessive absorbed water can deteriorate the membrane's mechanical strength, chemical stability, and dimensional stability due to the weakened hydrogen bonding interactions and Van der Waals forces caused by polymer swelling [35,87]. It has been reported that the tensile strength of the membrane decreases by about $25-30 \%$ with the addition of $10 \%$ water [88].

\section{Proton Conduction Mechanism}

The proton conductivity of PEMs is measured by the electrochemical impedance spectroscopy (EIS) technique. Generally, the proton conductivity of a membrane can be calculated using the following equation (Equation (1)) [89]:

$$
\sigma=\frac{L}{R A}
$$


where $\sigma, L, R$, and $A$ are the proton conductivity $\left(\mathrm{S} . \mathrm{cm}^{-1}\right)$, the membrane thickness $(\mathrm{cm})$, the membrane resistance $(\Omega)$, and the membrane effective surface area $(\mathrm{cm})$, respectively. The activation energy $\left(E_{a}\right)$, which is the minimum energy required for transferring protons in a membrane, can determine the predominated mechanism of the ionic transport in PEMs [90]. The activation energy of proton transfers decreases with a decrease in the proton transfer resistance in PEMs. An increase in temperature could usually result in a decrease in resistance [91]. The activation energy of a membrane can be obtained by the Arrhenius form of conductivity equation (Equation (2)) as follows [92,93]:

$$
\sigma=\sigma_{0} \exp \left(-\frac{E_{a}}{R T}\right)
$$

where $\sigma_{0}$ is the pre-exponential factor, $E_{a}$ is the activation energy of the proton conductivity, $R$ is the gas constant $\left(8.314 \mathrm{~J} \cdot \mathrm{mol}^{-1} \cdot \mathrm{K}^{-1}\right)$, and $\mathrm{T}$ is the temperature $(\mathrm{K})$.

Numerous reports have studied the proton conduction mechanism in PEM fuel cells; however, the exact mechanism of proton conduction in the PEMs has not been fully recognised and understood yet. Among the various theories introduced so far, the 'vehicular' and 'Grotthuss' mechanisms have been more commonly approved to explain the proton transfer mechanisms in PEMs [94,95]. Usually, the PEMS with activation energy below $14 \mathrm{KJ} . \mathrm{mol}^{-1}$ can be explained better with the 'vehicular' mechanism, while those exhibiting higher activation energies are better represented with the 'Grotthus' mechanism [96]. In fact, the proton transfer explained by both the 'vehicular' and Grotthus mechanisms does not act independently in PEMs. Both theories can make helpful assistances to better understand the proton conduction mechanism in PEMs. The proton transfer happens with a 'vehicle' or proton solvent (for example, water molecules as hydrates in the PEM molecular structure) that provides a suitable diffusion rate in the 'vehicular' mechanism [97]. In the 'Grotthuss' mechanism known as the 'hopping' mechanism, a vehicle or proton solvent is not essential. Protons could simply jump from one site to another alongside the proton acceptor sites in the PEMs backbone $[27,98]$. Figure 4 displays a schematic diagram illustrating both the 'vehicular' and 'hopping' mechanisms for proton conduction paths in PEMs [99,100].

\section{Proton Vehicular mechanism Proton hopping mechanism}

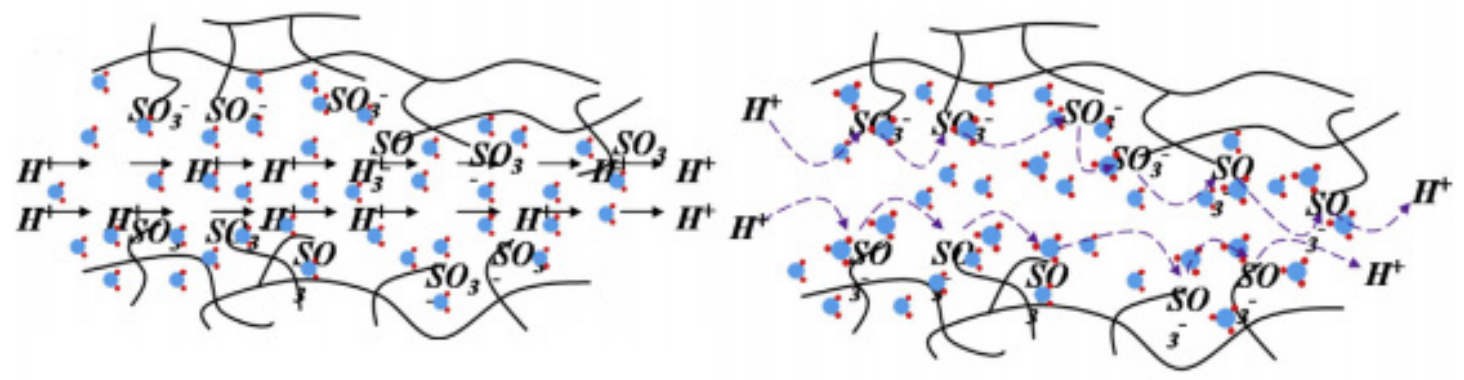

Figure 4. The schematic design of the vehicular mechanism and hopping mechanism as proton conduction in PEMs. Reproduced from [99], Elsevier: 2015.

In general, both Grotthuss and vehicular mechanisms are present in the PEMs and contribute to the total proton conductivity. It has been reported that the vehicular mechanism is the dominant mechanism in the sulphonic-contained PEMs. In the presence of water, the Grotthus mechanism contributes to the proton migration via the breaking and forming of hydrogen bonds in water molecules [101]. On the other hand, the vehicle mechanism is the predominant mechanism in the membranes in which the protons can be diffused freely and transported by charge carriers in a liquid, i.e., water molecules act as a vehicle for proton migration [102]. At low temperatures and in the membranes containing $N$-heterocycle such as imidazole, the vehicular mechanism is still predominant, but the contribution of 
the Grotthus mechanism increases dramatically [103]. In an anhydrous proton-conducting membrane, the Grotthus mechanism is mainly responsible for proton conductivity [101]. At elevated temperatures, keeping the water within the membrane becomes more difficult. In this case, the Grotthus mechanism becomes the dominant mechanism of proton conductivity in HT-PEMFCs [104,105]. Proton conductivity of the plain Nafion decreases with increasing operating temperature. The proton conductivity of Nafion membranes (particularly at higher temperatures) can be improved by incorporating the solvents such as heterocycles [106]. In the case of blending membranes, such as sulfonated poly(ether ketone) (SPEEK) membranes, introducing the benzimidazole group into the hydrophilic domains can promote the Grotthus mechanism, which results in improving the proton conductivity of the membrane [107].

One of the most critical factors affecting the proton conductivity $(\sigma)$ of PEMs is the viscosity of solvents $(\eta)$, which can be expressed by a combination of the StokesEinstein equation (Equation (3)) and the modified Nernst-Einstein equation (Equation (4)) as follows [108]:

$$
\begin{gathered}
D=\frac{K T}{c \pi \eta r} \\
\sigma=\frac{N e^{2}}{K T}\left(D_{+}+D_{-}\right) \alpha
\end{gathered}
$$

where $D$ is the self-diffusion coefficient of the ionic species $\left(D_{+}\right.$and $D_{-}$are the diffusion coefficients of the ions), $K$ is the Boltzmann constant, $T$ is the absolute temperature, $r$ is the Stokes radius of the ion, $c$ is a constant calculated with the boundary situations, $N$ is Avogadro's number, e is the electric charge, and a represents the degree of dissociation. Substituting Equation (3) into Equation (4) would result in a new equation (Equation (5)) to express the proton conductivity as a function of the key factors, including the degree of dissociation, temperature, viscosity, and the Stokes radius of the ions $\left(r_{+}\right.$and $\left.r_{-}\right)$as follows:

$$
\sigma=\frac{N e^{2}}{C \pi \eta}\left(\frac{1}{r_{+}}+\frac{1}{r_{-}}\right) \alpha
$$

\section{Polymer Electrolyte Membrane Types}

\subsection{PEM Types}

As explained, the proton-exchange polymer electrolyte membranes are classified into two major categories: LT-PEMs and HT-PEMs. The LT-PEMs are used in transportation and mobile devices operating at approximately $60-80^{\circ} \mathrm{C}$. The fuel impurities, such as carbon monoxide, hydrogen sulfide, and heat rejection, are the main challenges in developing LT-PEMs $[109,110]$. The purpose of developing HT-PEMs (at temperatures $>120^{\circ} \mathrm{C}$ ) is to overcome the disadvantage of LT-PEMs. The evaporation of water in LT-PEMs such as perfluorinated-based PEMs causes a decrease in the proton transport pathway [35]. A mixture of liquid- and gas-phase water may coexist during the LT-PEMs fuel cells operation, which complicates the PEM fuel cell electrodes [111]. In the past couple of decades, the LTPEMs fuel cells operation has received great attention to improve their CO tolerance level, lower the use of precious metals, better heat and water management, facilitate the electrode reaction kinetics, and gain higher electrochemical performance. Currently, the main focus of the HT-PEMs research and development community is to control the high degradation rate of PEMs, long start-up and shutdown procedures, and the cell durability at higher temperatures $[28,112,113]$. Table 1 compares the main factors affecting the operation of the LT-PEMs and HT-PEMs. 
Table 1. Comparison between LT-PEMs and HT-PEMs. Reproduced from [114], Elsevier: 2017.

\begin{tabular}{ccc}
\hline Item/Factor & LT-PEMs & HT-PEMs \\
\hline Membrane & Perfluoro sulfonic/sulfonated & PBI-based polymer \\
blectrode & based polymer & Pt-C or Pt alloys \\
Oper Pt alloys \\
Efficiency & $70-80{ }^{\circ} \mathrm{C}$ & $120-180^{\circ} \mathrm{C}$ \\
Operating pressure & $40 \%$ & $45-50 \%$ \\
Proton carrier & Ambient pressure & Ambient pressure \\
CO tolerance & Water & Inorganic acids \\
Other impurities & $<50$ ppm & $1-3 \%$ by volume \\
Water management & Low & Higher \\
Heat management & Complex & None \\
Reaction rate & Complex & None \\
\hline
\end{tabular}

The HT-PEMs exhibit a higher gradient of the temperature concerning the environment temperature. This higher temperature difference is an advantage as it can provide a better driving energy heat transfer for cooling purposes, and hence, the HT-PEM stacks can be more compact using the effective supplementary servicing units $[112,115,116]$. On the other hand, the higher operating temperature can also result in having a longer start-up/shutdown time with more stringent requirements to keep the thermomechanical stability of the components during the operation $[112,116,117]$. The HT-PEMs such as acid-doped polybenzimidazole (PBI) can efficiently conduct protons even in anhydrous conditions [118]. Cell operating with no humidification requirements can facilitate the system design by decreasing water management issues in PEM fuel cells. Although, there are also LT-PEM fuel cells that do not require the humidification process, where the water produced in the cathode is enough to wet the Nafion membrane for efficient proton conduction [119]. Nonetheless, water management remains a critical aspect of LT-PEM fuel cells because of the existence of water in the liquid phase [120]. Due to operation at temperatures above the boiling point of water (in the present in vapour state), the HT-PEM fuel cells need a simple system.

\subsection{High-Temperature PEMs Based on PBI}

In general, achieving an acceptable electrochemical performance with a PEM fuel cell requires a high proton conductivity in its heart, which is a PEM layer $[121,122]$. The use of the Nafion membrane as the most widely used PEMs is limited due to its high cost, comparably large fuel crossover, poor mechanical reliability, and the risk of polymer structure rupture at the operating temperatures above $100{ }^{\circ} \mathrm{C}[123,124]$. On the other hand, HT-PEM fuel cells offer many benefits, such as providing more prominent working voltage, alleviating the effect of $\mathrm{CO}$ poisoning in electrodes, and gaining better cell efficiency [125]. PBI has been reported to be used in the HT-PEM fuel cell membrane because it can provide excellent chemical, thermal, oxidative, and hydrolytic stability at high temperatures [126]. Figure 5 shows the chemical structure of PBI, which is one the most common material used in HT-PEMs.<smiles>CC(C)(C)c1cccc(-c2nc3ccc(-c4ccc5nc(C(C)(C)C)[nH]c5c4)cc3[nH]2)c1</smiles>

Figure 5. The chemical structure of polybenzimidazole (PBI).

It has been commonly accepted that the proton conductivity mechanism in the PAdoped PBI-based high-temperature PEMs is extensively controlled with the 'Grotthus' 
mechanism (transference number of $\mathrm{t} \sim \mathrm{H}^{+}$97.5\% for PA) [127]. The concentration of PA is an important factor influencing the proton hopping in the Grotthus hopping mechanisms. The PA-doped PBI membranes have lower proton conductivity compared to neat liquid PA, which has the highest intrinsic proton conductivity $[33,128]$. Just $2.6 \%$ of the entire proton conductivity of PA-PBI-based HT-PEMs is controlled with the 'vehicular' mechanism [129]. The proton conductivity of PA-PBI-based HT-PEMs is increased by an increase in relative humidity [130]. A rise in RH can increase the molecular interaction between free PA sites (amino groups of PBI and water in PA-PBI-based HT-PEMs). It has been reported that the packed-acid mechanism as a subderived mechanism based on the 'Grotthus' mechanism can identify the materials with significantly concentrated (packed) acids. The packed-acid mechanism, which was not specific to PBI, involves the conduction of protons without the movement of water [131].

PBI with different compositions can be synthesized from hundreds of tetraamine and diacid combinations. Specifically, PBI refers to the proprietary product CelazoleR, poly 2,2-m-(phenylene)-5,5-benzimidazole. The aromatic nuclei of PBI, as an amorphous thermoplastic polymer, provide the polymer with strong thermal-stability (glass-transition temperature, $\mathrm{T}_{\mathrm{g}}=425-436^{\circ} \mathrm{C}$ ), excellent chemical tolerance, stiffness durability and hardness, yet low processability, as already mentioned [57,132,133]. Due to its unusual self-ionization, self-dehydration, and nonvolatile properties, PA is commonly used as a proton conductor under high-temperature operating conditions [22,134]. Because of the fundamental character of PBI, which could produce a robust acid-base interaction, PA-doped PBI membranes have been regarded as the most effective HT-PEMs in recent decades $[135,136]$. The amount of PA loading into the PBI is one of the most prominent because the quantity of PA dictates the PEM's proton conductivity, which in turn determines the efficiency of the fuel cell. In general, a higher PA load yields higher proton conductivity and thus enhances fuel cell performance $[29,137]$. The PA in PA-doped membranes is eventually dehydrated into polyphosphoric acid. Thus, the proton conductivity gradually decreases during cell operation under typical operating temperature [133]. For PA-doped PBI membranes, proton conductivity is expected to be lower compared to liquid PA, since in this case, the polymer partially interrupts the Grotthus chains between $\mathrm{PA}$ and the ion pair $\mathrm{H}_{4} \mathrm{PO}_{4}{ }^{+} / \mathrm{H}_{2} \mathrm{PO}_{4}{ }^{-}$. Only about $2.6 \%$ of the total conductivity accounts for conductivity via the 'vehicular' mechanism through the diffusion of dissociated ions. Hence, it can be concluded that PA conduction is predominantly protonic with a proton transfer number close to unity $\left(\mathrm{t} \sim \mathrm{H}^{+}\right.$97.5\%) and suggested structural diffusion (Grotthus mechanism) as the primary mechanism of conduction [133,138]. At low concentrations of PA, the 'Grotthus' hopping mechanisms are mainly between species $\mathrm{H}_{3} \mathrm{O}^{+}$and $\mathrm{H}_{2} \mathrm{O}$, and at high concentrations of $\mathrm{PA}$, there is an increasing amount of proton hopping between molecules $\mathrm{H}_{4} \mathrm{PO}_{4}{ }^{+}$and $\mathrm{H}_{3} \mathrm{PO}_{4}$ [138].

After immobilisation, PA by itself is not supposed to be stabilized as it is affected by severe leaching phenomena. This, in turn, reduces the efficiency of the fuel cell that has been reported elsewhere [49]. One of the primary issues in the PA-PBI membranes is the leaching of PA from PBI membranes over the longer-term operating periods [139,140]. More attempts have recently been made to modify the PA-PBI membranes, including PBI crosslinking, PBI sulfonation, PBI analogue structure preparation, PBI-based blend membrane synthesis, and composite and nanocomposite membrane synthesis. In order to improve the thermal and mechanical stability of PA-doped PBI-based composite membranes, Rajabi et al. [141] used SBA-15 mesoporous silica (MDASBA-15), and 1,3-di(3-methylimidazolium) propane dibromide dicationic ionic liquid $\left(\mathrm{pr}(\mathrm{mim}){ }_{2} \mathrm{Br}_{2}\right)$, which was a new generation of ionic liquids containing two mono anions and two single-charged cations known as dicationic ionic liquids. Two aromatic rings connected by an alkyl chain can make up the cations in the dicationic ionic liquids. The dicationic ionic liquids offer a higher glass-transition temperature, melting point, thermal stability, and proton conductivity compared to the monocationic ones [118,142]. In HT-PEM fuel cells, ionic liquids are used to improve the proton conductivity of membranes [32]. However, in a long-term operation under high 
temperatures, the tendency of dicationic ionic leakage from the membranes is an effective factor in reducing proton conductivity [118].

The PA doping level is not only the question of usable acids and the membrane types but also the function of concentrations of acid solvents [120]. The PA doping level increases rapidly at the very poor concentration up to $0.5 \mathrm{MPA}$, as shown in Figure 6a. On the other hand, the higher concentration ranging from 2-10 MPA, can slowly increase the rate of PA doping. The PA doping level rate again increases sharply above a high concentration (13 MPA) at room temperature. In the HT-PEM fuel cell, the proton conductivity of the acid PBI membrane is strongly correlated with temperature and the PA doping level at the anhydrous condition. From Figure $6 \mathrm{~b}$, it can be seen that the conductivity of acid-doped

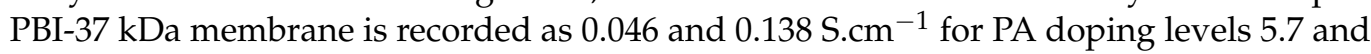
11.5 under $180^{\circ} \mathrm{C}$, respectively [57]. PA undergoes several compositional transformations and changes in HT-PEM fuel cell operating conditions through interactions with water and the PBI membrane, resulting in proton conductivity and viscosity variations as reported by Korte et al. [138]. They concluded that a fraction of $15 \mathrm{wt} . \%$ of pyrophosphoric acid $\left(\mathrm{H}_{4} \mathrm{P}_{2} \mathrm{O}_{7}\right)$ is formed from $100 \mathrm{wt} . \% \mathrm{PA}$, at an equilibrium temperature above $200{ }^{\circ} \mathrm{C}$, and that a two-phase liquid aqueous PA and water field results in preferential water evaporation until the thermodynamic equilibrium is reached in a PA-water system.
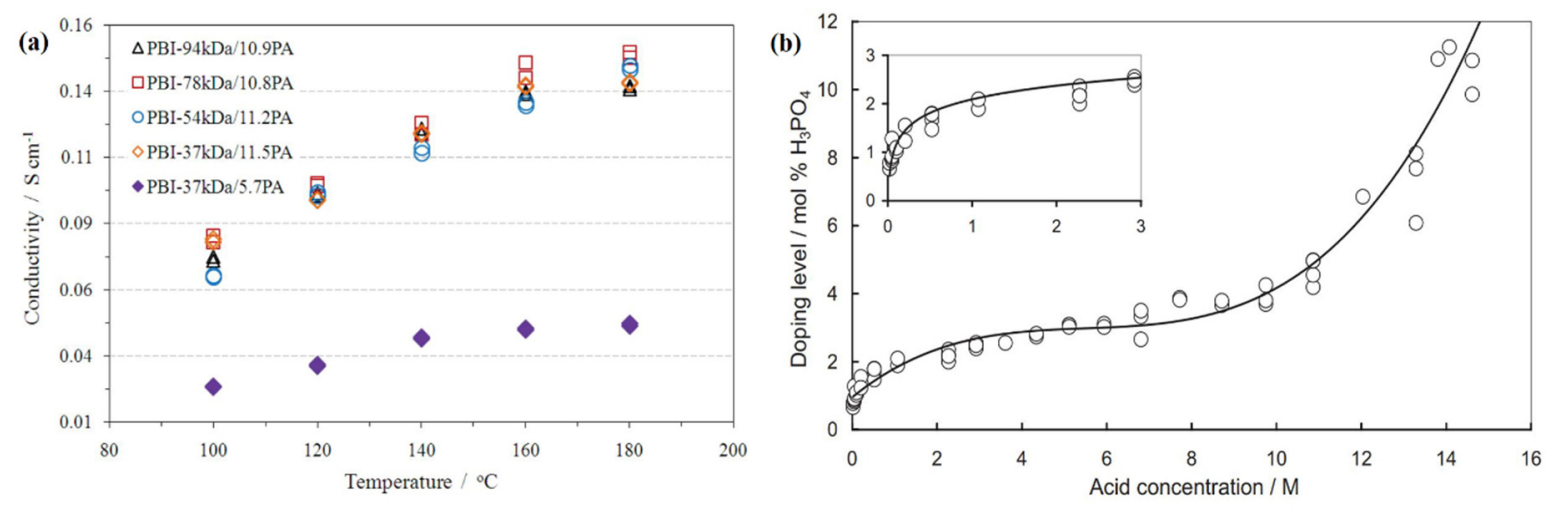

Figure 6. Graphical representation of (a) proton conductivity of PA doping of different molecular weight of PBI membrane at different temperatures (Reproduced from [57], Elsevier: 2014); (b) the PA doping level rate of different concentrated PA-doped PBI membrane at room temperature; (Reproduced from [46], Elsevier: 2004).

Ogawa et al. [131] propose another process obtained from the "Grotthus" mechanism known as the "packed-acid" mechanism that involves the conduction of protons without water movement and is usually seen in materials that consist of highly concentrated (packed) acids and low humidity conditions. Their work was not particular to PBI, but in the acid environment of acid-doped PBI membranes, the mechanism may be important, especially since structural diffusion requires water movement or fluctuation, while no water movement is required in the packed acid. Due to the lack of water inside the membrane, the highly efficient Grotthus-type mechanism for proton diffusion is limited under low RH. Proton conductivity increases with an increase in RH for the PA-PBI membranes (2-8\%) [11]. This is because intermolecular interaction between water, free $\mathrm{PA}$, and imino groups are formed $\left(\mathrm{PA}\left(\mathrm{H}_{2} \mathrm{PO}_{4}{ }^{-}\right) \ldots\right.$ water $>\mathrm{PA} \ldots \mathrm{H}_{2} \mathrm{PO}_{4}{ }^{-}>\mathrm{N}-\mathrm{H}^{+} \ldots \mathrm{H}_{2} \mathrm{PO}_{4}{ }^{-}, \mathrm{N}-\mathrm{H}^{+} \ldots$ water $>\mathrm{N}^{-} \mathrm{H}^{+} \ldots \mathrm{N}-\mathrm{H}$ ), which decreases the aggregation of PA in the PBI matrix [11]. The PA doping range for pure PBI membranes is 6-10 mol. The pure PBI membranes displays 22, $30,40,50,55$, and $20 \mathrm{mS} \mathrm{cm}^{-1}$ at $80{ }^{\circ} \mathrm{C}$ [141], $100{ }^{\circ} \mathrm{C}$ [118,142], $140{ }^{\circ} \mathrm{C}$ [130], $160{ }^{\circ} \mathrm{C}$ [143], and $180^{\circ} \mathrm{C}$ [124], respectively in dry conditions. The conductivity of protons in PA/PBI systems depends on temperature, acid doping, and relative humidity $(\mathrm{RH})$. Excess PA, however, follows a decline in its mechanical characteristics and results in a phenomenon of 'elution' within the membranes. Furthermore, at high temperatures, free acid departs from the fuel cell configuration with evaporating moisture. Ma et al. [144] and Guan et al. [145] claimed that the temperature dependence could be interpreted with an Arrhenius equation. 
Some experiments showed that the proton conductivity of a PA/PBI system does not increase with temperature at temperatures above $160{ }^{\circ} \mathrm{C}$. Moreover, Korte et al. [138] reported that the proton conductivity of concentrations above $10 \mathrm{wt} \% \mathrm{P}_{2} \mathrm{O}_{5}(\sim 14 \mathrm{wt} . \% \mathrm{PA})$ shows a significantly non-Arrhenius temperature dependence. On the other hand, $\mathrm{RH}$ and acid-doping levels positively affect conductivity, as can be seen from the following PBI protonation processes and excess $\mathrm{PA}$ and $\mathrm{H}_{2} \mathrm{O}$ equilibrium reactions [22].

Three series of PBI copolymers (3,5-pyridine-r-2OH-PBI, 3,5-pyridine-r-para-PBI, and 3,5-pyridine-r-meta-PBI) were synthesized using polyphosphoric acid (PPA) processes and copolymerized membranes. At $180^{\circ} \mathrm{C}$ and anhydrous condition, a maximum ionic conductivity of $279 \mathrm{mS} . \mathrm{cm}^{-1}$ was achieved with the membranes prepared with the highest proton conductivity. The monomer pairs with high- and low-solubility characteristics have been used in order to define phase stability-processing windows for the preparation of membranes with high-temperature membrane gel stability [146]. In this regard, Kumar et al. [147] synthesised a random copolymer series of PBI containing alicyclic and aromatic backbones by using two different dicarboxylic acids (i.e., dicarboxylic acid and terephthalic acid cyclohexane) by varying their molar ratios. With an increase in the aliphatic content, the interaction between PBI chains has shown a decrease. A more ordered structure with one copolymer composition (CHTA-30) has exhibited the highest conductivity of $242 \mathrm{mS} . \mathrm{cm}^{-1}$ at $160{ }^{\circ} \mathrm{C}$. The ordered structure allows most of the doped acid to be in the 'bonded form,' which may create a total pathway of conduction that may be the rationale for enhanced conductivity. The proton conduction mechanism follows the 'Grotthuss' mechanism with a very low $10.8 \mathrm{~kJ} \mathrm{~mol}^{-1}$ activation energy. The membrane also showed good oxidative stability with $16.2 \%$ weight loss. As a highlight, the polymer backbone structure can be tuned in such a way that it shows a more orderly structure, good proton conductivity, enhanced doped mechanical properties, and reasonably good copolymerization oxidative stability. Therefore, the aliphatic-aromatic PBI copolymerization path can be adaptable to the operating condition of the high-temperature fuel cell membranes. In another work, meta-/para-PBI random copolymer membranes were synthesised via PA

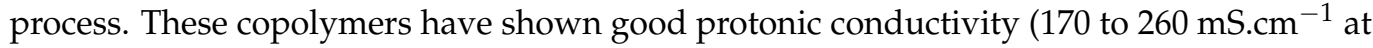
$180^{\circ} \mathrm{C}$ ) when prepared with acid doping (in the cases of using 12 and 10 PA/PBI repeating units). However, the mechanical strength of these samples at low-doped conditions was only about $7 \mathrm{MPa}$ (tensile strength) and $11 \mathrm{MPa}$ (Young's modulus), respectively [148].

Due to their good mechanical properties, moderate gas permeability, and superior proton conductivity under high-temperature operation, PA-doped PBI membranes have received attention. Among PBI-based film membranes, nanofibrous membranes withstand higher stress due to strongly oriented polymer chains while exhibiting a higher specific surface area with an increased number of proton-conducting sites [149]. Changes in proton conductivity and morphology of electrospun PA-doped nanofibers were monitored by Jahangiri et al. [149]. The manufactured PBI electrospun nanofiber mats were systematically optimized based on fibre diameter and fibre morphology, and the best results were obtained for the PBI-9 system of 15 different scenarios with a mean fibre diameter of $170 \mathrm{~nm}$.

It has been reported that meta-PBI membranes can be crosslinked by just heating up to 350-500 ${ }^{\circ} \mathrm{C}$ temperatures. Joseph et al. [90] suggested that this mechanism of crosslinking involves the first diamine and acid hydrolysis of imidazole groups, followed by a FriedelCrafts reaction between the PBI carboxylic acid groups and phenyl rings. More often, crosslinked PBI membranes are obtained by reacting with an alkylating agent with the nitrogen atoms of PBI. Nucleophiles at elevated temperatures can attack these links [150]. Joseph et al. [150] introduced a new method to crosslink PBI by avoiding $\mathrm{N}-\mathrm{CH}_{2}-\mathrm{links}_{\text {, }}$ starting from ironically crosslinked membranes of acid/base blend. A Friedel-Crafts reaction can take place between sulfonic acid groups and electron-rich phenyl groups that could covalently crosslink the acid and base components in the mixture through chemically stable aromatic sulfone bonds (by heating them to temperatures above $200{ }^{\circ} \mathrm{C}$ ). According to the literature, pure PBI can also be cured, and a radical mechanism was proposed by involving the air. It has been shown that PBI in an inert atmosphere can also be cured. 
Joseph et al. suggested that a slightly higher temperature (than the membrane blending process) should be used to cure the pure PBI thermally. This is because of the fact that the thermal curing process can proceed through imidazole hydrolysis to - $\mathrm{COOH}$ and diamine, followed by Friedel-Crafts reaction to acid. They have studied the effect of temperature and time on the membrane properties such as solubility, absorption of PA, and mechanical properties, by testing their thermally crosslinked membranes in a fuel cell, proving that the membranes are gas-tight and perform well [150].

Numerous attempts were proposed to modify PA-PBI membrane defects, including crosslinked structure preparation, PBI sulfonation, PBI-based mixing membranes synthesis, and composite and nanocomposite membrane synthesis. Sulfonation of PBI membranes is one of the successful approaches in the aforementioned series that could provide higher proton conductivities around $376 \mathrm{mS} . \mathrm{cm}^{-1}$ at $180{ }^{\circ} \mathrm{C}$ [151]. Typically, three common approaches are used to functionalize PBI: (1) direct backbone sulfonation; (2) chemical grafting of functionalized monomers; and (3) polycondensation of a sulfonated aromatic diacid with an aromatic tetraamine. The last technique offers more benefits compared to the first two, such as achieving limited side reactions and controlling the level of sulfonation [48]. Many experiments have been carried out on membranes with doping levels of 28-53 mol PA/PBI at elevated temperatures, and almost all of them demonstrated achieving an excellent conductivity [152].

Several high-temperature PBI-based PEMs with perovskite and doped-perovskite nanoparticles have recently been investigated $[34,62,93]$. For the use in PEM fuel cells, the remarkable properties of perovskite structure materials have attracted great attention. Materials of the perovskite-type mainly absorb inorganic fillers for PEMs at high temperatures due to their high thermal stability and suitable conductivity of the protons [153]. Perovskites with a wide range of chemical and physical properties have a chemical formula of $\mathrm{ABO}_{3}$ where $\mathrm{A}$ (A cations are 12-coordinated by oxygen and have a large ionic radius of the same size as the oxygen ion) and $\mathrm{B}$ (B cations are 6-coordinated by oxygen and have a small ionic radius located in the octahedral holes between the closed $\mathrm{AO}$ layers) are the appropriate cations $[125,154,155]$. The stable structure of perovskite oxides is due to their balanced geometry and valence of the basic atoms. Doped-perovskite nanoparticles of barium strontium titanate $\left(\mathrm{Ba}_{0.9} \mathrm{Sr}_{0.1} \mathrm{TiO}_{3}\right)$ (BST) [121] and lanthanum strontium chromate $\mathrm{La}_{0.9} \mathrm{Sr}_{0.1} \mathrm{CrO}_{3-\delta}$ (LSC) [36] are the preeminent encouraging materials with numerous uses, including gas sensors, capacitors, infrared detectors, and solid oxide fuel cells. The substitution of $\mathrm{Sr}^{2+}$ creates various types of vacancies with $\mathrm{Ba}^{2+}$ and $\mathrm{La}^{3+}$ in the A-site of BST and LSC doped-perovskite nanoparticles. In the LSC doped-perovskite nanoparticles, the $\mathrm{Sr}^{2+}$ dopant creates cation vacancies in the BST nanoparticles and the oxygen vacancies. In increasing proton conductivity, oxygen vacancies play a more significant role than cation vacancies. The oxygen vacancies in the LSC doped-perovskite nanoparticles increase the conductivity of the protons because of their role as hydrogen traps $[138,156]$. Reducing the ionic repulsion between positive charges and hydrogen ions and thereby increasing hydrogen jumping are the major effects of doping in LSC doped-perovskite nanoparticles [143].

By condensing polymerization of biphenyl-4,40-diyldi(oxo)-4,40-bis(1,8-naphthalene dicarboxylic hydride) (BPNDA), 2-(4-aminophenyl)-5-amino benzimidazole (APABI), and 4,40 diaminodiphenylether (ODA) in m-cresol in the presence of benzoic acid, Yuan et al. [157] synthesized poly (imidebenzimidazole) random copolymers and quinoline at $180{ }^{\circ} \mathrm{C}$ for $20 \mathrm{~h}$. The improvement of films with high doping levels (and therefore high proton conductivity) with low trade-offs in terms of mechanical quality is strongly desired from the standard application perspective. In the literature, this problem has been extensively addressed, and several approaches have been considered, such as various crosslinking concepts [57], linear molecular weight increase [133], block copolymerization [158], and polymer synthesis with acidic or basic suspended groups or with modified polymer backbones $[133,138,159]$. The aromatic polyimides (PIs) are another family of engineering plastics known for their outstanding thermal stability, high mechanical 
strength and modulus, superior electrical properties, and good chemical resistance [160]. Thus, they have found wide applications in the industry. These merits are just what the polyelectrolyte membranes used in fuel cells with PEM require. A series of novel poly(imidebenzimidazoles) were synthesised and extensively characterised in the research works based on their properties, including acid doping, mechanical behaviour, and proton conductivity behaviour under various conditions and cell operations $[149,161]$. It is expected that the combination of basic benzimidazole groups in random copolymer structures can facilitate acid absorption. By contrast, poor interactions between polyamide units and doped acid molecules are expected to improve mechanical strength compared with benzimidazole units.

Immobilised protonic liquids have been used to prepare PBI-based PEMs as alternative electrolytes $[139,162]$. When nanoparticles are functionalized with ionic liquids, the membrane leaching of ionic liquids decreases and thus increases the proton conductivity. Mixing acidic polymers with PBI to achieve good proton conductivity up to $200 \mathrm{mS}^{-\mathrm{cm}^{-1}}$ at $180^{\circ} \mathrm{C}$ is another approach that can be taken into account for anhydrous PEMs. Some papers have reported the strategies used for the preparation of high proton conductivity PBI-based miscible alloy membranes with good mechanical-dimensional stability and appropriate electrochemical performance by incorporating the polymers with intrinsic microporosity [2]. Polymer blending is a cost-effective and easy method to manufacture novel polymeric materials with improved physical and chemical properties merely by mixing polymers. Acid protons (from the acid-mixing component) are subjected to be transferred into the basic imidazole sites in the acid-base blend membranes that can form a crosslinked ionic structure [163]. Tashvigh and et al. [132] reported that the mixing of sulfonated polyphenylsulfone and PBI increased PBI membranes' chemical stability. Sulphonated aromatic polymers could be proper candidates to be used in HT-PEM fuel cells [54]. Heteroaromatic polymers can exhibit a high conductivity at high temperatures in the anhydrous environment because they have rings such as pyridine, pyrazole, triazole, and imidazole that are considered to be acceptable components for making the blend membrane operate at high temperatures [164]. The sulfonated polyimides can offer an appropriate level of proton conductivity due to their hydrophilic domain, which acts as an efficient shell transporting the protons. The development of alternatives to sulfonated perfluoropolymers is one of the promising methods to make sulfonated aromatic polymers and has received great attention in the literature. For instance, in a study, SPI was derived from the new diamine-containing thiazole heterocycle rings [33].

Preparation of composite membranes with the introduction of hydrophilic inorganic particles of SBA-15 mesoporous silica has also been reported in fuel cell applications [165]. The unique properties of SBA-15 mesoporous silica include tube-shaped pores with a hexagonal structure covered by the silanol $(\mathrm{Si}-\mathrm{OH})$ groups, pores with a diameter greater than $2 \mathrm{~nm}$, lower toxicity, greater biocompatibility, and better biodegradability [166]. In addition, the outer surfaces of SBA-15 mesoporous silica were covered with a negative surface charge for the Si-OH groups. In these membranes, the $\mathrm{Si}-\mathrm{OH}$ groups act as the active sites for uptaking PA and proton transmission. Many studies showed that SBA-15 mesoporous silica pores have a significant impact on the absorption of PA and can increase the ability of the membrane to retain PA [167].

The sulfonated PBI (sPBI)/sulfonated imidized graphene oxide (SIGO) is another potential candidate for developing HT-PEM fuel cells that have been mainly proposed in order to solve the disadvantages associated with sPBI polymers such as low proton conductivity, poor water uptake, and ion exchange capacity [130]. Imran et al. [168] incorporated multifunctionalised covalently bonded SIGO into the sPBI matrix synthesized by direct polycondensation in PA for the application in PEMs. The results showed the formation of interconnected hydrophobic graphene sheets by establishing organic polymer chains with strong hydrogen bonding among multifunctional groups. This can offer a hydrophobic-hydrophilic phase separation and an easy architecture for the proton hopping mechanism [168], as the chemical structure of Nafion with high proton conductivity follows 
the same principle [169]. Incorporating graphene oxide can improve the proton conductivity and the physical and mechanical properties of the resulting membrane because of the presence of the functionalised GO nanoparticles in the resulting composite. SIGO content has been added to the sPBI polymer matrix to improve proton conductivity, but the primary drawback of sPBI synthesised by direct polymerization was its water retention capabilities. The multifunctional GO covalently bonded with sPBI was synthesized by a method known as the 'surface imidization' technique in order to incorporate high-content nanofillers and to prevent their aggregation and leaching out of the polymer matrix [168].

Cai et al. [170] successfully prepared RGO with a high ion exchange capacity by blending it with PBI to obtain a series of PBI/RGO membranes. The PA doping level of $\mathrm{PBI} / \mathrm{GO}$ or PBI/RGO membranes remains almost unchanged (217-222 wt.\%) with the rise of the GO or RGO content due to the interactions between the oxygen-containing groups, $\mathrm{PA}$, and the imidazole ring. The results showed that the mechanical strength and chemical stability of these membranes are acceptable. By immersing the PBI/RGO/P in Fenton's solution for six days, the membrane with an RGO content of $1 \mathrm{wt} . \%$ could be obtained that shows a tensile strength of $38.5 \mathrm{MPa}$ at room temperature with a remaining mass of about $89.0 \%$. These composite membranes could demonstrate that introducing RGO and PA with a higher proton conductivity at high temperatures is achievable.

The composite and nanocomposite-based PBI membranes have been developed with high proton conductivity up to almost $310 \mathrm{mS} . \mathrm{cm}^{-1}$. The mechanical properties and proton conductivity of the PBI-based membranes could be enhanced by various methods such as thermal crosslinking of PBI [150], crosslinking with phenylsulfonated $\mathrm{TiO}_{2}$ (as both the filler and the crosslinking agent) [126], and the formation of a highly acidophilic imidazolerich crosslinking network $[49,171]$. There have been studies of different membranes based on strong proton conductors such as ferric sulfophenyl phosphate (FeSPP) [172], cerium sulfophenyl phosphate (CeSPP) [130], zirconium sulfophenyl phosphate (ZrSPP), and PBI [172]. Incorporating FeSPP in the PBI matrix as an insoluble proton conductor not only could provide a robust high-temperature proton conductivity but also improve the dimensional stability and the oxidative resistance of the resulting membrane. This was mainly because of achieving a better dispersion, the formation of more proton channels, and improved physicochemical properties due to building a hydrogen-bonding network between PBI and FeSPPP sites [173]. The composite and nanocomposite-based ionic liquid membranes listed in Table 2 are also considered as the PBI-based membranes with high protonic conductivity at anhydrous conditions (with a conductivity of about $370 \mathrm{mS} . \mathrm{cm}^{-1}$ at $\left.180^{\circ} \mathrm{C}\right)[139,151,174]$. Table 2 represents a summary of the highest proton conductivity for different membranes reported in the recent literature.

Table 2. Proton conductivity of PBI-based membranes under anhydrous conditions.

\begin{tabular}{|c|c|c|c|c|}
\hline Membrane Type & Reinforcement & Temperature $\left({ }^{\circ} \mathrm{C}\right)$ & $\begin{array}{l}\text { Proton Conductivity } \\
\quad\left(\mathrm{mS} . \mathrm{cm}^{-1}\right)\end{array}$ & Ref \\
\hline \multirow{2}{*}{ Sulfonated } & $-\mathrm{SO}_{3} \mathrm{H}$ groups & 180 & 373 & {$[48]$} \\
\hline & $-\mathrm{SO}_{3} \mathrm{H}$ groups & 180 & 324 & [151] \\
\hline \multirow{9}{*}{ Composite } & Inorganic Al-Si & 150 & 309.58 & [175] \\
\hline & Ionic liquids & 180 & 293 & [162] \\
\hline & Protic ionic liquids & 180 & 293.15 & [162] \\
\hline & Acidic surfactant & 180 & 280 & [140] \\
\hline & Poly(phosphoric acid) & 200 & 255.14 & [152] \\
\hline & Heterocyclic benzo[c]cinnoline & 160 & 251 & [129] \\
\hline & Arylether-type PBI & 200 & 233.81 & [27] \\
\hline & Bulky pendants (phenyl and methylphenyl & 200 & 215 & [154] \\
\hline & $\begin{array}{c}\text { Dendrimer amines functionalized SBA-15 } \\
\text { mesoporous silica }\end{array}$ & 180 & 202 & [141] \\
\hline
\end{tabular}


Table 2. Cont

\begin{tabular}{|c|c|c|c|c|}
\hline Membrane Type & Reinforcement & Temperature $\left({ }^{\circ} \mathrm{C}\right)$ & $\begin{array}{l}\text { Proton Conductivity } \\
\left(\mathrm{mS} \cdot \mathrm{cm}^{-1}\right)\end{array}$ & Ref \\
\hline & a-Zirconium phosphate & 160 & 198.29 & [176] \\
\hline & $\begin{array}{c}\text { Poly } \\
{[2,20-(\text { p-oxydiphenylene })-5,50-\text { benzimidazole }]}\end{array}$ & 160 & 188.93 & [38] \\
\hline & $\mathrm{SiO}_{2}$ & 300 & 186.75 & [177] \\
\hline & Graphene oxide & 180 & 170.40 & {$[24]$} \\
\hline & Triazole modified graphene oxide & 180 & 135.30 & [178] \\
\hline & Siloxane & 180 & 133.52 & [179] \\
\hline & Branched block PBI & 180 & 156.96 & [159] \\
\hline & Functionalized PBIs & 180 & 152.41 & [114] \\
\hline & Poly(Vinylbenzyl Chloride) & 160 & 109.58 & [180] \\
\hline & Guaternary ammonium groups & 170 & 103.31 & [181] \\
\hline & Zeotypes/protic ionic liquids & 170 & 101.80 & [182] \\
\hline & Sulfophenylated $\mathrm{TiO}_{2}$ & 150 & 94.98 & [29] \\
\hline Copolymer & 3,5-Pyridine-PBI & 180 & 279.38 & [146] \\
\hline \multirow{7}{*}{ Nanocomposite } & Ionic liquid/ nano $\mathrm{SiO}_{2}$ & 180 & 239 & [139] \\
\hline & Protic ionic liquid modified silica & 160 & 238.17 & [139] \\
\hline & Titanium dioxide & 180 & 199.52 & [183] \\
\hline & $\mathrm{BaZrO}_{3}$ & 180 & 125.14 & [135] \\
\hline & Clay & 160 & 117.05 & [96] \\
\hline & $\mathrm{Ba}_{0.9} \mathrm{Sr}_{0.1} \mathrm{TiO}_{3}$ & 180 & 103 & [144] \\
\hline & $\mathrm{Fe}_{2} \mathrm{TiO}_{5}$ & 180 & 102.73 & [127] \\
\hline \multirow{6}{*}{ Blend } & $\begin{array}{l}\text { Sulfonated polyhedral oligosilsesquioxane } \\
\text { composite }\end{array}$ & 180 & 193.18 & [184] \\
\hline & Lignosulfonate & 160 & 186.89 & [185] \\
\hline & Lignosulfonate & 180 & 186 & [186] \\
\hline & $\begin{array}{l}\text { Poly(vinylidene fluoride-co-hexafluoro } \\
\text { propylene) }\end{array}$ & 160 & 165 & [187] \\
\hline & Lignin & 160 & 150.18 & [185] \\
\hline & Poly(vinyl imidazole-co-vinyl phosphonic acid) & 160 & 106.32 & [39] \\
\hline
\end{tabular}

\section{Degradation and Fuel Cell Performance}

The degradation of the PA-doped PBI-based membrane can be initiated by the chemical degradation, which happens by H-containing end-groups attacked with hydrogen peroxide and its radicals that finally results in a mechanical/thermal degradation [133]. The $\mathrm{N}-\mathrm{H}$ bond attack in the imidazole ring causes a ring-opening for imidazole and 'scission' of the macromolecular chain, which can be studied by FTIR spectra. In the PA-doped PBI membranes, the PA has an inhibiting effect on the decomposition of $\mathrm{H}_{2} \mathrm{O}_{2}$ and hence can decrease the chemical degradation of the PBI membrane [133]. A research study in this field has reported that the PBI membrane displayed a 15\% weight loss after $20 \mathrm{~h}$ of exposure to a $3 \% \mathrm{H}_{2} \mathrm{O}_{2}$, which was higher than that of the Nafion 117 membrane [188]. In another study, the stress at the break of the PBI membrane dropped from 52.9 to 33.9 MPa due to the peroxide attack [189]. The physical properties can be considered to be an essential factor in the degradation of the PEMs. Deformation of the membrane, which takes place due to the compressive forces of the bipolar plates in MEAs, leads to pinhole formation and can decline the chemical degradation of the PEMs [190]. The swelling and shrinking of the PBI membrane can cause mechanical stress to the membrane [36]. According to thermal stability results, there is no significant weight loss at 150 and $500{ }^{\circ} \mathrm{C}[191,192]$. The PA converts to pyrophosphoric acid at lower temperatures (ranging from 140 to $180{ }^{\circ} \mathrm{C}$ ). The platinum and its alloys, which are extensively used as a catalyst for the fabrication of HT-PEM fuel cells, have a more or less similar degradation mechanism to LT-PEM fuel cells [193]. During the long-term operation of the HT-PEM fuel cells, the diameter of nanoscale platinum particles is increased due to being dissolved into platinum ions and 
platinum agglomeration. Therefore, the active surface area in the electrode structure would be decreased. The dissolved platinum particles are transferred to those parts of the MEA structure, making it difficult to access the reaction sites [194,195].

The platinum catalyst in an HT-PEM fuel cell faces more challenges compared to that of an LT-PEM fuel cell. In the acidic environment of HT-PEM fuel cells, the dissolved platinum at the nano- and atomic-scale can precipitate in the membrane by reducing platinum ions [196]. This phenomenon can be confirmed by TEM analysis (Figure 7a,b) [197]. The attachment of platinum particles on the carbon support surface is weakened by increasing the operating temperature $[26,196]$. The detachment of platinum particles in the catalyst layer occurs due to carbon support corrosion [198]. The growth in the average particle size of platinum catalyst in MEA is one of the key degradation mechanisms during the long-term steady-state operation of HT-PEM fuel cells [133]. The catalyst degradation leads to the decay of the fuel cell performance mainly at the initial stage of the cell operational lifetime [199]. The price, performance, and durability are three major parameters affecting the commercialization of fuel cell technologies. Hence, it is necessary to consider a target number for the durability and lifetime of the fuel cell, e.g., based on the DOE (the US Department of Energy) set targets [133]. Table 3 summarizes the degradation rates for PBI-based fuel cells under the steady-state and transient-state conditions at a temperature between 150 and $180{ }^{\circ} \mathrm{C}$. As can be seen in Table 3, a longer lifetime is achieved at the steady-state condition. In addition, in the steady-state condition, the reduced amount of water formation can cause less acid leaching, which results in gaining a more stable voltage that can eventually minimise the carbon support and catalyst degradation. At the transient-state condition, more water would be formed. Therefore, the cell components face a greater level of thermal and mechanical stress. The corrosion of carbon support and catalyst growth can also occur at the transient-state condition [112]. The other reasons can be listed as the components failure, membrane thinning, catalyst support corrosion, nonhomogenous dilution, and sintering of catalyst nanoparticles or by unstable operating parameters, insufficient reactant supply, high operating temperature, fuel impurities, and transient loading for low durability and the degradation issue [112].
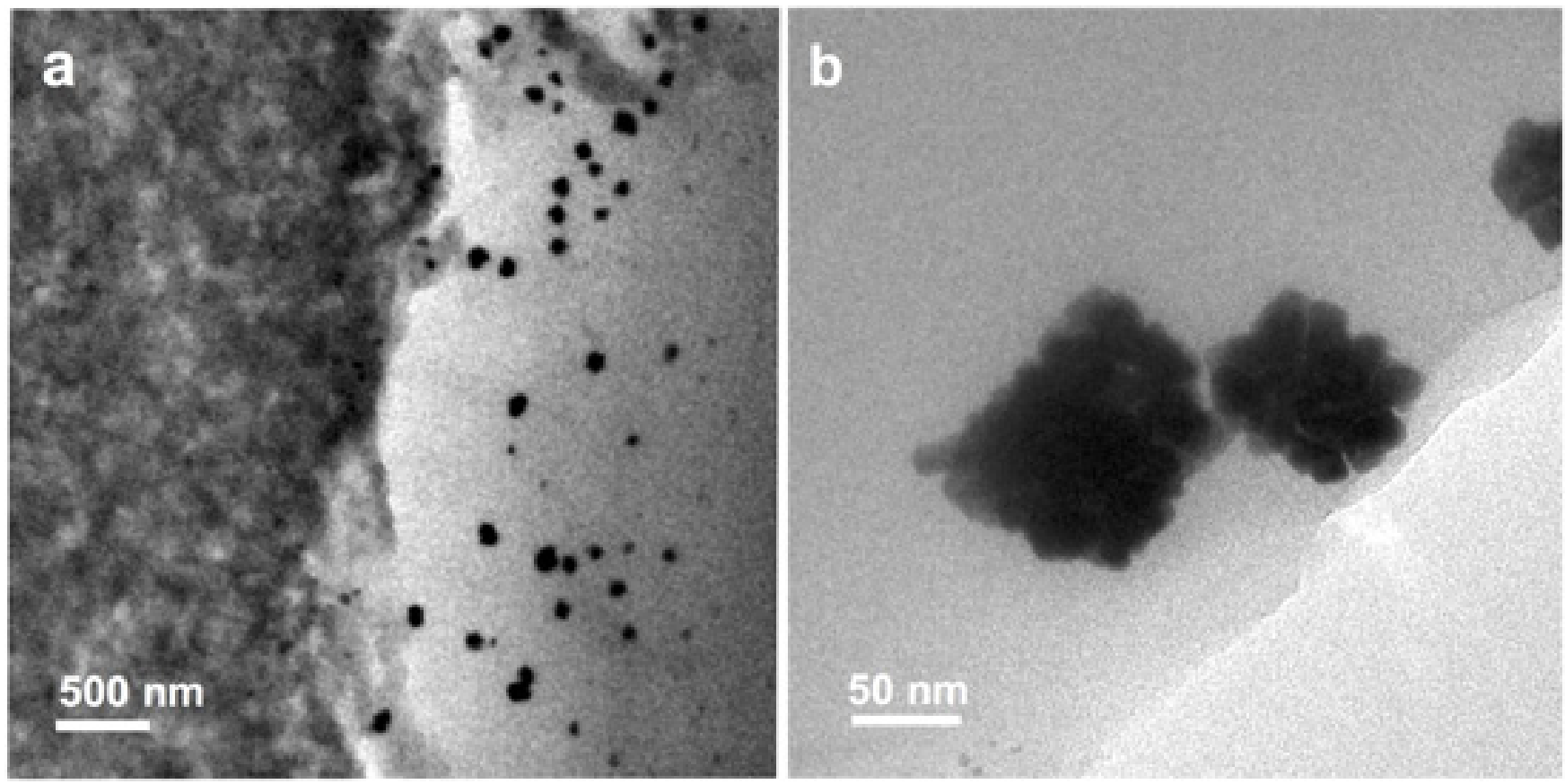

Figure 7. The STEM image of redeposition of Pt aggregates into the membrane in MEA-Pt/C, (a) disordered commercial Pt catalyst, (b) ordered commercial Pt catalyst. Reproduced from [197] IOP: 2020. 
Table 3. The degradation rate of PBI fuel cell under steady-state and transient-state conditions at a temperature between 150 and $180^{\circ} \mathrm{C}$.

\begin{tabular}{cccc}
\hline Lifetime & Condition & Decay Rate $\left(\boldsymbol{\mu} \mathbf{V} \cdot \mathbf{h}^{-\mathbf{1}}\right)$ & Reference \\
\hline$>1500 \mathrm{~h}$ & $160^{\circ} \mathrm{C}, 0.3 \mathrm{~A} \cdot \mathrm{cm}^{-2}$ & 1.5 & {$[57]$} \\
$>2000 \mathrm{~h}$ & $160^{\circ} \mathrm{C}, 0.3 \mathrm{~A} \cdot \mathrm{cm}^{-2}$ & $2.4-6.5$ & {$[112]$} \\
$>2000 \mathrm{~h}$ & $180-200{ }^{\circ} \mathrm{C}$ & $<5$ & {$[146]$} \\
$>2300 \mathrm{~h}$ & $180^{\circ} \mathrm{C}, 0.2 \mathrm{~A} \cdot \mathrm{cm}^{-2}$ & 5.2 & {$[146]$} \\
$6000 \mathrm{~h}$ & $160^{\circ} \mathrm{C}$ & 25 & {$[146]$} \\
$>6000 \mathrm{~h}$ & $180^{\circ} \mathrm{C}$ & 19 & {$[200]$} \\
$18,000 \mathrm{~h}$ & $160^{\circ} \mathrm{C}$ & $5-6$ & {$[201]$} \\
$4000 \mathrm{~h}$ & $180^{\circ} \mathrm{C}, 0.2 \mathrm{~A} \cdot \mathrm{cm}^{-2}$ & 19 & {$[202]$} \\
\hline
\end{tabular}

For the preparation of MEAs, the PEMs and electrodes should be assembled. The MEA can be fabricated by two major methods, including the catalyst-coated substrate (CCS) [182] and the catalyst-coated membrane (CCM) [112]. In the CCS method, the prepared catalyst ink is directly deposited on the gas diffusion layer that is fabricated as a catalysed gas diffusion layer. Then, the catalysed gas diffusion layer is directly hot-pressed onto the membrane surface under a high temperature and pressure that results in making an MEA $[28,112]$. In the CCM method, the catalyst ink is deposited onto the membrane instead of the gas diffusion layer [28]. Table 4 has summarized the electrochemical performance of the PBI membrane-based fuel cells (measured at $0.5 \mathrm{~V}$ under a dry atmosphere). The performance of the PBI-based membranes depends on the operation conditions of a fuel cell and the membrane properties $[93,137]$. The temperature and proton conductivity have a notable influence on the fuel cell performance of PBI-based PEMs. Increasing the temperature due to the fast kinetics of proton transfer would improve the fuel cell performance. The key parameter to achieve a high fuel cell performance is gaining a high proton conductivity by the membranes, making it possible to gain a high power density $[93,113,203]$. As shown in Table 4 , the high current density $\left(>1 \mathrm{~A} . \mathrm{cm}^{-2}\right)$ was reported for the PBI-based membranes, which is quite comparable with the commercial Nafion membranes.

Table 4. Fuel cell performance of PBI-based membranes in $0.5 \mathrm{~V}$ and dry conditions.

\begin{tabular}{|c|c|c|c|}
\hline Reinforcement & $\mathrm{T}\left({ }^{\circ} \mathrm{C}\right)$ & $\begin{array}{l}\text { Current Density } \\
\quad\left({\left.\mathrm{A} . \mathrm{cm}^{-2}\right)}^{-2}\right.\end{array}$ & Ref \\
\hline Sulfophenylated $\mathrm{TiO}_{2}$ & 150 & 0.75 & [139] \\
\hline Poly(vinyl imidazole-co-vinyl phosphonic acid) & 80 & 1.2 & [186] \\
\hline Graphene oxide & 165 & 0.69 & [29] \\
\hline Guaternary ammonium groups & 160 & 0.8 & [182] \\
\hline Branched block PBI & 160 & 1.26 & [181] \\
\hline Protic ionic liquids & 200 & 0.48 & [180] \\
\hline $\begin{array}{l}\text { Sulfonated polyhedral oligosilsesquioxane } \\
\text { composite }\end{array}$ & 160 & 0.791 & [132] \\
\hline Heterocyclic benzo[c]cinnoline & 160 & 2.25 & [114] \\
\hline $\mathrm{BaZrO}_{3}$ & 180 & 1.12 & [135] \\
\hline $\mathrm{SiO}_{2}$ & 250 & 0.6 & [178] \\
\hline Bulky pendants (phenyl and methylphenyl & 160 & 0.55 & [24] \\
\hline Arylether-type PBI & 160 & 0.72 & [177] \\
\hline $\mathrm{Fe}_{2} \mathrm{TiO}_{5}$ & 180 & 0.76 & [127] \\
\hline Sulfonating & 160 & 0.6 & [151] \\
\hline $\begin{array}{l}\text { Melamine-based dendrimer amines functionalized } \\
\text { SBA-15 mesoporous silica }\end{array}$ & 180 & 1.18 & [118] \\
\hline Triazole modified graphene oxide & 180 & 1 & [176] \\
\hline Poly(Vinylbenzyl chloride) & 180 & 0.625 & [154] \\
\hline $\mathrm{Ba}_{0.9} \mathrm{Sr}_{0.1} \mathrm{TiO}_{3}$ & 180 & 1.24 & [144] \\
\hline
\end{tabular}


The polarization curves are primarily described with three separate regions: activation polarization, ohmic loss, and concentration polarization [204]. An increase in the operating temperature can positively influence cell performance by decreasing the ohmic loss of the membrane. In the MEAs made by PBI, there is an indirect relation between temperature and the ohmic loss, which is due to decreasing the ohmic resistance of the membrane because of the improved current of ions through electrolytes [13,205]. Gaining an optimal operational condition with the MEAs is one of the fundamental necessities for developing the HT-PEMs.

\section{Experimental Characterization}

\subsection{In Situ Characterisation}

The polarization curve named the I-V curve can be measured by less expensive electrochemical devices and methods. The method can be conducted using a potentiostatgalvanostat analyser over a range of temperatures and hydrogen/oxygen flow rates [206]. The impedance spectroscopy and cyclic voltammetry are known as more expensive methods compared with the polarization curve $[207,208]$. In this method, the electrical current is changed, and the equivalent voltage output is measured and plotted against the current density. The voltage output is an important parameter as well that shows the figure of merit for a fuel cell [209]. There are different procedures to record the polarization curves, such as the European and US DOE protocols. In these procedures, the current density is gradually increased from a nominal operating point to the maximum load by reducing the open-circuit voltage [133]. The hysteresis effect on the performance of the polarization curve due to the direction of the electrical current sweep in sequential protocols can decrease the fuel cell performance in the LT-PEMFC [210]. The hysteresis effect can be related to the high dependence of LT-PEM fuel cell performance on humidity, which is less critical in HT-PEM fuel cells. AC impedance spectroscopy is an effective characterisation technique, typically mentioned as the electrochemical impedance spectroscopy (EIS), to study the ionic conduction and charge-transport behaviour within the operation of the fuel cell [133].

\subsection{Ex Situ Characterization}

Ex situ characterization techniques can be used complementarily with in situ electrochemical techniques. These techniques significantly affect PEM fuel cells' progress, particularly to understand the morphology of their component and stability [211,212]. The Raman spectroscopy, infrared (IR), and nuclear magnetic resonance (NMR) spectra have been used to explore the PEMs and their protonation by different acids $[24,36,133]$. Most of the informative $\mathrm{N}-\mathrm{H}$ stretching modes for pure PBI occur in this range from 2000 to $4000 \mathrm{~cm}^{-1}$ [135]. The sharp peak centred at $3415 \mathrm{~cm}^{-1}$ and broad absorption band located around $3145 \mathrm{~cm}^{-1}$ are attributed to nonbonded "free" $\mathrm{N}-\mathrm{H}$ groups and hydrogen-bonded N-H groups, respectively [132]. For PA-doped PBI membranes, an extensive absorption band in $2400-3000 \mathrm{~cm}^{-1}$ is observed due to protonation of the nitrogen of the imide by PA [149]. The band at $1630 \mathrm{~cm}^{-1}$ is sensitive to the protonation for all the acids after reaching the maximum degree of protonation [36]. For the PA-doped PBI membranes, the crystalline properties decrease due to the plasticizing effect of PA. The remarkable $\mathrm{T}_{\mathrm{g}}$ decline was detected using differential scanning calorimetry (DSC) for PA-doped PBI membranes [49].

Raman spectroscopy can be used to investigate spectroscopic properties such as the effects of PA-doping and acid-base interaction on PA-PBI-based PEMs [138]. Raman spectra of PBI and PA-doped PBI have been reported. The FT-Raman band at $1000 \mathrm{~cm}^{-1}$ was attributed to the meta-benzene ring vibration $[13,36]$. Raman spectroscopy can also be used to investigate the interaction of water vapour with PA-doped PBI/polysulfone-based blends. The scanning electron microscopy (SEM) and transmission electron microscopy (TEM) are the other well-known two-dimensional ex situ analyses that are used for the investigation of the membrane and MEA morphology, nanoparticle dispersion, phase 
separation, etc. Particle size distribution, the location of particle size growth, and average particle diameter can be examined in TEM imaging. The TEM imaging technique cannot recognize particles smaller than $1 \mathrm{~nm}$, and it comparably shows a larger particle size than the XRD analysis. X-ray tomography is a three-dimensional structural analysis that uses a three-dimensional model of the object without destroying it [133]. Previous researchers used the method along with the electrochemical procedures to examine fuel cell performance.

In addition to the in situ and ex situ analyses, several methods have been employed to measure the electrochemical impedance spectroscopy (EIS) of the PEMs, including in-plane, through-plane, two-probe, four-probe, etc. A summary of the different possible configurations (geometry and analysis techniques) for the EIS measurements is shown in Figure 8.

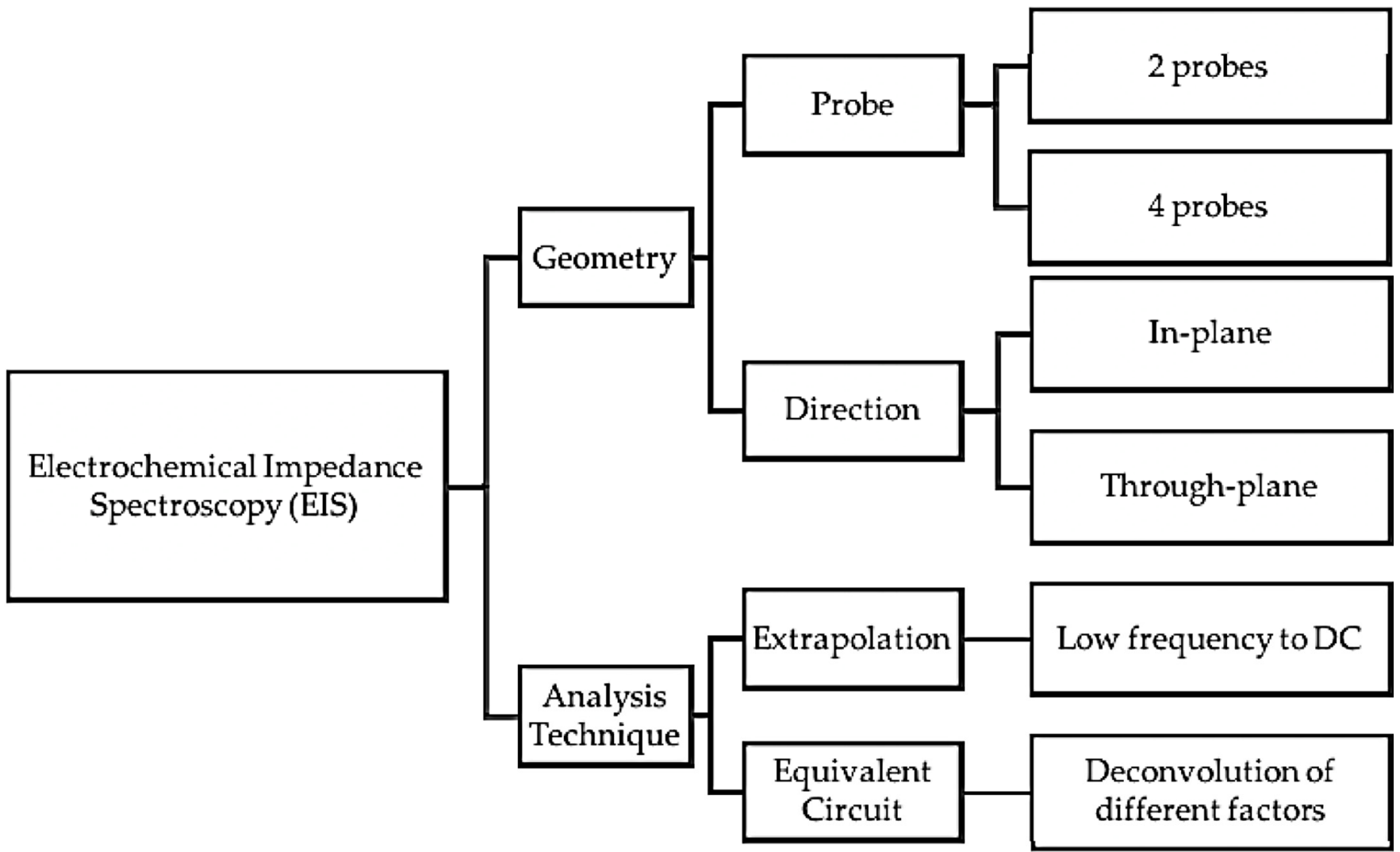

Figure 8. Possible configurations for EIS measurement. Reproduced from [213], MDPI: 2017.

\subsection{In-Plane and Through-Plane Techniques}

In-plane conductivity $\left(\sigma_{\|}\right)$measurement is a technique in which two platinum plate electrodes and a sheet of the sample (membrane) are mounted on a Teflon cell, and two parallel Pt electrodes are placed on one side of the membrane. To measure the proton conductivity in liquid water or at relative humidity lower than $100 \%$, the cell is placed in a distilled deionized water or a humid chamber with controlled humidity (thermos-controlled humid chamber), respectively. In-plane conductivity can be calculated as follows [214-217]:

$$
\sigma_{\|}=d / t l R
$$

where $d, t, l$, and $R$ are the distance between the electrodes, the thickness of the membrane, the width of the membrane, and the resistance of the membrane. For the case with liquid water, a fully hydrated state should be used for the dimensions [214]. A schematic of in-plane test setup configuration is shown in Figure 9. 


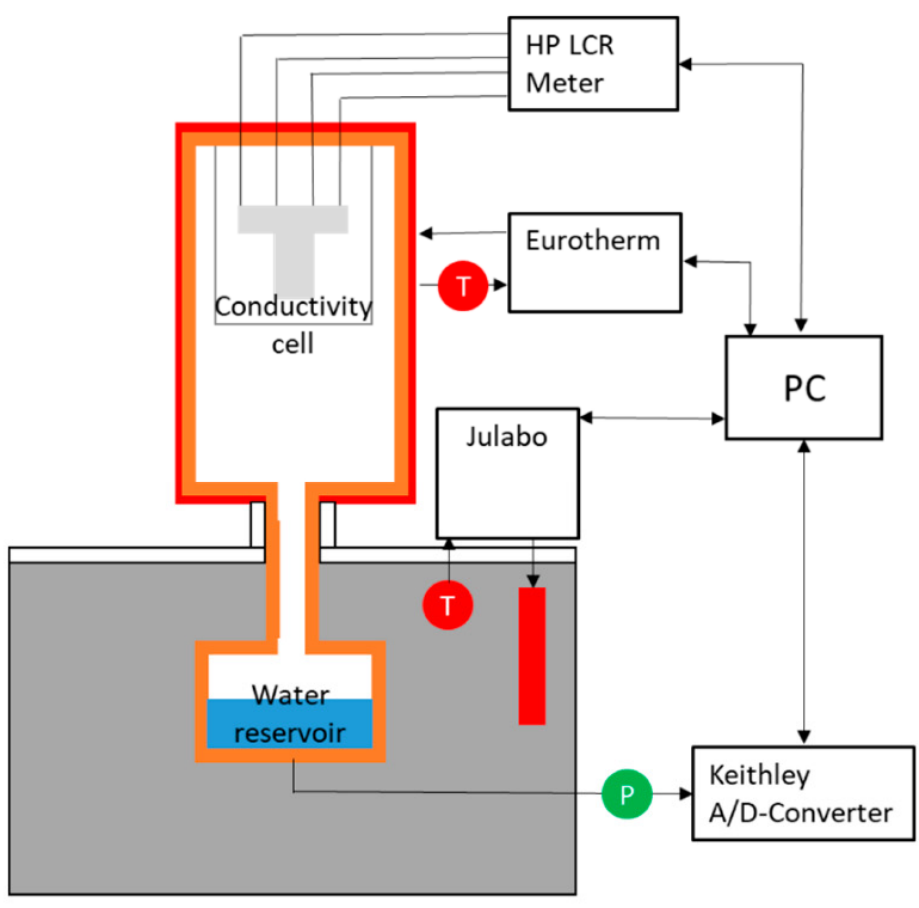

(a)

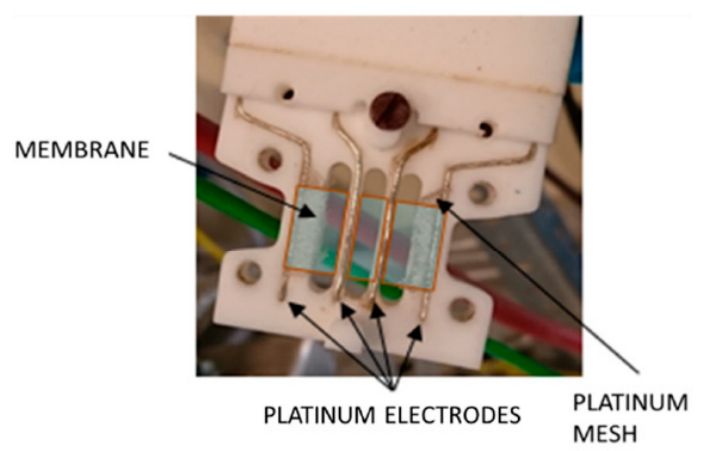

(b)

Figure 9. Schematic of in-plane test setup (a) experimental arrangement, (b) in-plane measurement cell. Reproduced from [216], MDPI: 2019.

Another technique for measuring the proton conduction is through-plane conductivity $\left(\sigma_{\perp}\right)$. The test setup is comprised of two PTFE blocks that build the framework, and the membrane sheet is placed between two Pt electrodes. To determine the resistance, the high-frequency intercept of the impedance with the real axis should be used. The following equation can be used for the through-plane conductivity calculations [214-216]:

$$
\sigma_{\perp}=t / A R
$$

where $t$ is the thickness of the membrane, $A$ is the effective area of the electrode, and $R$ is the membrane resistance. A sample arrangement of the through-plane test setup configuration is shown in Figure 10. 


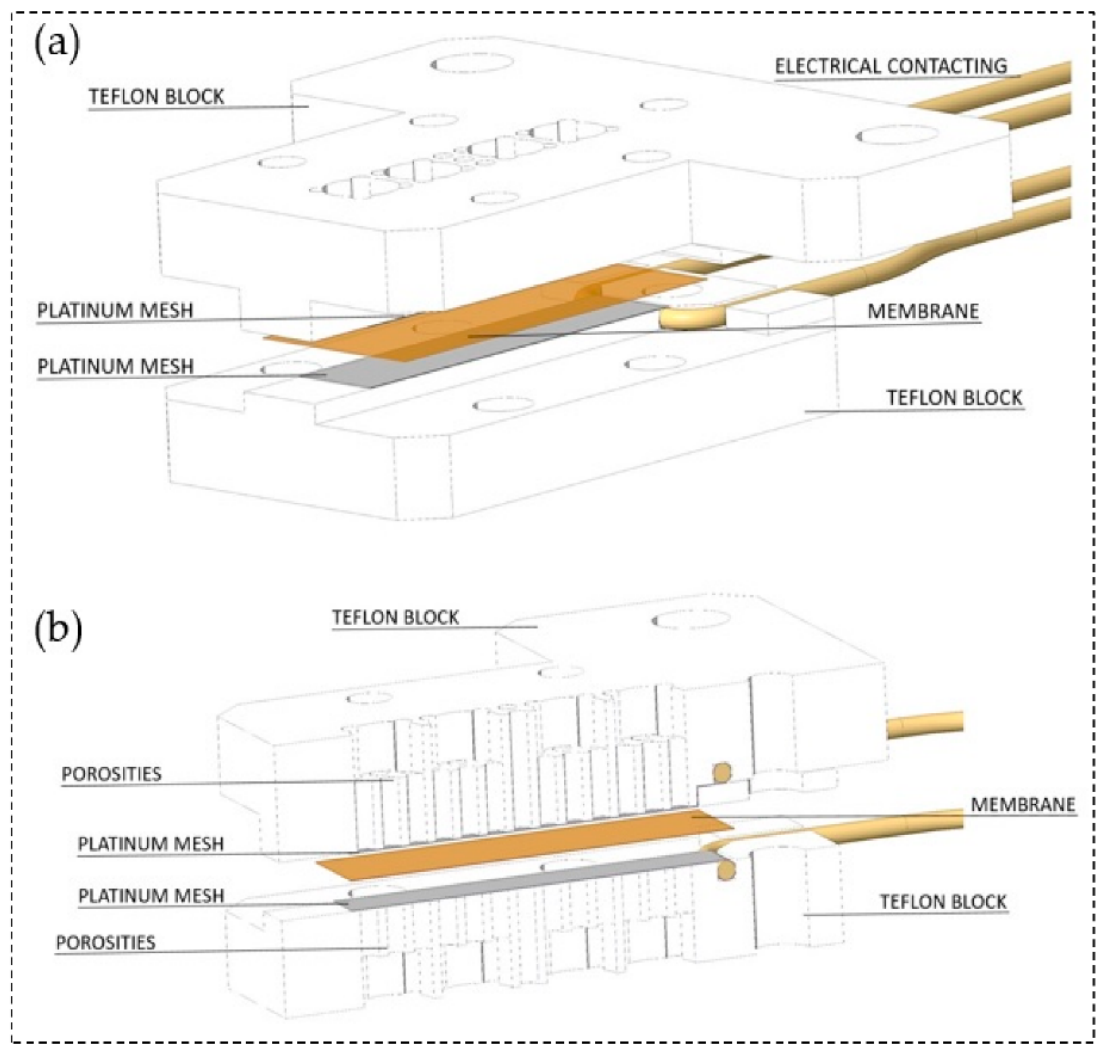

Figure 10. Schematic of through-plane test set-up (a) through-plane impedance cell arrangement, (b) cross section of through-plane impedance cell. Reproduced from [216], MDPI: 2019.

The through-plane method is more relevant since the diffusion of hydrogen ions happens through the membrane bulk [215]. However, due to difficulties with through-plane measurement, in-plane conductivity has been widely used for determining the proton conductivity of the PEMs [214]. The in-plane conductivity is greater than the through-plane conductivity, and the difference between these two values can be very significant. The main reason for the difference between these two methods is the anisotropic proton conductivity [214,217]. For example, Gardner and Anantaraman [218] reported a ratio of $\sigma_{\|} / \sigma_{\perp}=3.6$ for Nafion. This difference is even more significant for layered materials such as graphene oxide (GO) membrane fuel cell $\left(\sigma_{\|} / \sigma_{\perp}=170\right)$ [218]. In the case of anisotropic materials, this ratio can be even higher; thus, this issue should be carefully considered in determining the proton conductivity of the PEMs [215].

\subsection{The Two-Probe Electrodes and Four-Probe Electrodes Cells}

In terms of the functional probe configuration, the EIS measurement can be classified into two major groups: two-probe and four-probe configurations [213,219]. In the two-probe configuration, the electrodes operate under low frequencies and an alternating electric field. Before polarity reversal, some ions may reach the electrodes, and thereby the electric field in the membrane decreases (electrode blocking) [220]. In the four-probe configuration, the charge build-up effect near the electrodes diminishes because of using different electrodes with sufficient distance from the charge build-up region. The distance between the probes in both configurations plays an important in measuring the conductivity [213]. It has been reported that the two-probe configuration can be used for high-resistance materials because of the negligible impedance in the circuit. On the other hand, the four-probe arrangement is the appropriate choice for the ionic conducting materials with low resistivity due to the diminished interfacial effects in these materials [213]. A schematic of two-probe and four-probe configurations is shown in Figure 11. 


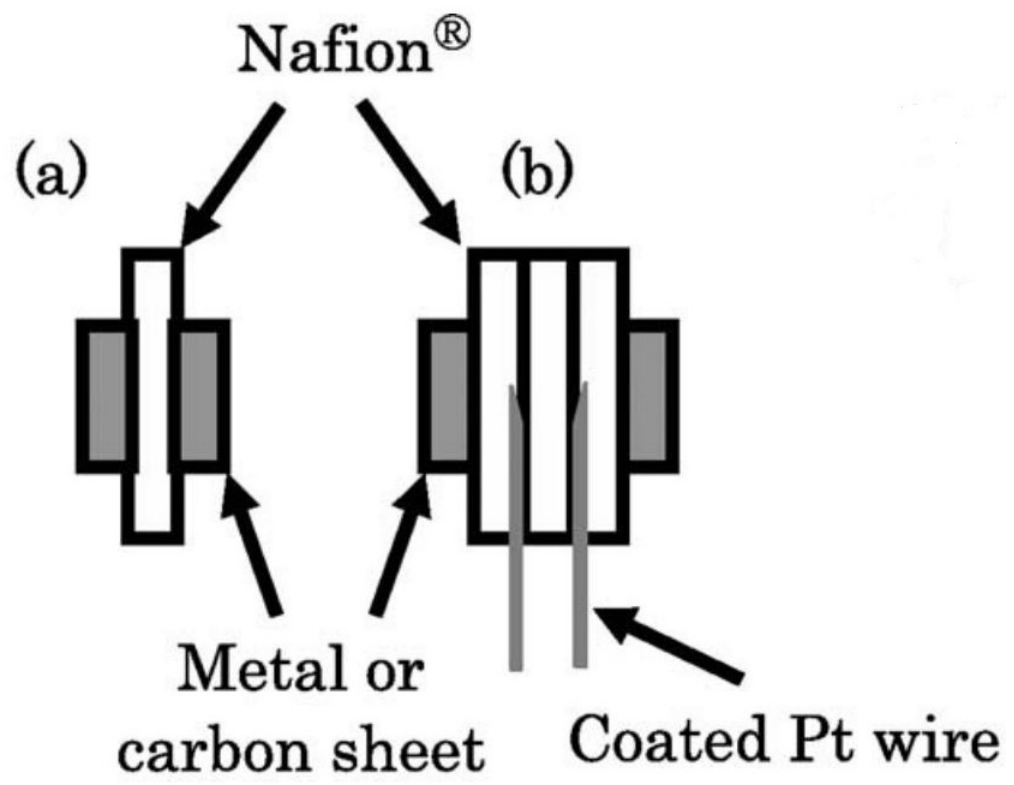

Figure 11. Schematic of (a) two-probe and (b) four-probe method arrangement. Reproduced from [221], IOP: 2006.

\subsection{Proton Conductivity and PA Doping Level}

The proton conductivity of PA-doped PBI membranes has been studied by several researchers. The researchers measured the anhydrous proton conductivity of different PA-doped PBI-based PEMs and proposed that the conductivity mechanism is dominated by the proton transfer from an $-\mathrm{N}$ site to a neighbouring vacant one by the phosphate counter-ion through a Grotthus mechanism. They confirmed counter-ion mobility by $1 \mathrm{H}$ and 31P NMR analysis [222]. The bound- and unbound-PA molecules and $\mathrm{H}_{2} \mathrm{PO}_{4}{ }^{-}$ anion in PA-doped PBI-based membranes mainly participate in the proton conduction through the 'Grotthus' mechanism [144]. Generally, the PA doping level $\left(\mathrm{PA}_{\mathrm{dop}}\right)$ has been achieved by dipping the membranes into PA (85 wt.\%) for five days [141]. In this method, the membranes were dried in a vacuum oven at $60{ }^{\circ} \mathrm{C}$ for $24 \mathrm{~h}$, and the doping level was determined by measuring the absorbed acid weight by the membranes. The results, represented by Equation (6), were used to calculate the PA $\mathrm{dop}_{\text {of }}$ of the membranes [22,186]:

$$
P A_{\text {dop }}=\frac{\left[W_{1}-W_{0} / M_{w} \text { of } P A\right]}{\left[W_{P B I} / M_{w} \text { of } P B I\right]}
$$

where $W_{0}$ and $W_{1}$ are the weights of the membranes before and after $P A$ doping, respectively.

The $P A$, as the proton carrier in an HT-PEM fuel cell, is widely analysed by using the energy disperse X-ray (EDX) technique together with the SEM and TEM methods [36,186]. The methods can be used to measure the PA content and its distribution in the MEA with time as well. The $\mathrm{pH}$ value measurement of the exhaust water as an ex situ technique (coupled plasma mass spectroscopy or chromatography) calculated the $P A$ loss rate during long-term operation $[223,224]$.

\subsection{Thermal, Chemical, and Mechanical Stability}

The Fenton test has been widely used to study the chemical degradation of PBI-based PEMs [118]. The chemical stability of PEMs is of much concern to the lifetime of PEM fuel cells. In the Fenton test, ferrous ions $\left(\mathrm{Fe}^{2+} / \mathrm{Fe}^{3+}\right)$ were used as the catalyst for $\mathrm{H}_{2} \mathrm{O}_{2}$ decomposition. The chemical stability of the PBI membrane (weight loss) was measured in $\mathrm{H}_{2} \mathrm{O}_{2}$ solutions with a trace amount of ferrous ions $\left(\mathrm{Fe}^{2+} / \mathrm{Fe}^{3+}\right)$ [133]. The $\bullet \mathrm{OH}$ or - $\mathrm{OOH}$ radicals form in situ from the decomposition of $\mathrm{H}_{2} \mathrm{O}_{2}$ and attack the polymer chain that has hydrogen bonding. The PEMs based on perfluorinated sulphonic acid 
such as Nafion display high chemical stability compared to those based on polyaromatic hydrocarbons [188].

The thermal stability of PBI membranes has been widely considered via thermogravimetric analysis (TGA) with mass spectrometry (MS) [127]. For pure PBI, weight loss at temperatures up to $150{ }^{\circ} \mathrm{C}$ is attributed to the absorbed water. Due to the outstanding stability of PBI, there is no important weight loss from 150 to $500{ }^{\circ} \mathrm{C}$. At temperatures over $500{ }^{\circ} \mathrm{C}$, a significant weight loss occurs due to the PBI backbone [225]. For the PA-doped PBI sample, weight losses due to dehydration of PA were observed above $140{ }^{\circ} \mathrm{C}$. Due to the strong hydrogen bonding between $\mathrm{N}$ and $-\mathrm{NH}$-groups as the main molecular force, the PBI membrane has high mechanical stability [142]. The dry PBI membrane has a small elongation at a break of around 1-3\% and an intermediate tensile strength of about $60-70 \mathrm{MPa}$ at RT compared with humidified PBI membrane. When PBI membranes are saturated with water, the elongation and tensile strength increase to about 7-10\% and 100-160 MPa, respectively [133]. In the PA-doped PBI membranes with a low acid-doping level range $(<2)$, the molecular cohesion between the PBI chains decrease, and the hydrogen bonding between $-\mathrm{N}$ atoms and PA increases the cohesion [36,118]. As a result, no important variation of the mechanical stability of the PBI membranes is observed. The PA-doped PBI membranes with a low acid-doping level range $(>2)$ have free PA. The free PA raises the separation for PBI backbones and so declines intermolecular forces and mechanical stability [179]. The mechanical stability of PA-doped PBI membranes is also strongly influenced by the average molecular weight of PBI. In a range from 20,000 to 55,000 g. mol ${ }^{-1}$, the tensile strength of PA-doped PBI membranes is found to increase from 4 to $12 \mathrm{MPa}$ [226].

\section{Challenges, Economic Viability, and Future Research Direction of High-Temperature PEM Fuel Cells \\ 8.1. Current Challenges}

The higher degradation rates and the slower start-up time are two major challenges of HT-PEMs [30]. The degradation rate increases with increasing operating temperatures. The start-up time rises when the operating temperature increases to above the boiling point of water to avoid the leaching of PA from the PBI-based membrane [112]. Cell durability is another significant challenge for HT-PEMs. The main objective of developing HT-PEMS is to achieve a durable cell operating with high performance. In terms of durability, a life period between 5000 and 40,000 h has been commonly approved for stationary power systems and portable stacks (such as automobile applications), respectively [227]. For the PBI-based membranes, the durability mechanisms include degradation of the polymer membranes, PA leaching from membranes, and finally, the loss of the catalyst activities [133]. The PA loss might happen over several mechanisms such as diffusion, capillary transport, membrane compression, and evaporation $[36,228]$. The PA leaching caused by the condensed water during the shutdown and cold start-up is one of the main reasons for degradation [28]. The $\mathrm{H}_{2} \mathrm{O}_{2}$ and its radicals $(\bullet \mathrm{OH}$ or $\bullet \mathrm{OOH})$ can attack PBI membranes in principal and start the degradation mechanism, which can be determined by arranging a Fenton test [57]. The other factors affecting the cell electrochemical performance are the catalytic activity loss due to the catalyst sintering, catalyst dissolution, catalyst layer fracture, and carbon support corrosion [36,112,195].

Figure 12 displays a set of durability test results for the PBI-based PEM fuel cells operating at ambient pressure. A lifetime of $5000 \mathrm{~h}$ has been achieved with a constant cell voltage of $0.5 \mathrm{~V}$ and $150^{\circ} \mathrm{C}$ by continuous $\mathrm{H}_{2} / \mathrm{O}_{2}$ operation. The lifetime showed a drop above $180{ }^{\circ} \mathrm{C}$ due to the oxidative polymer degradation. The oxidation with air seems much less effective than that of pure oxygen (Figure 12) [228]. 


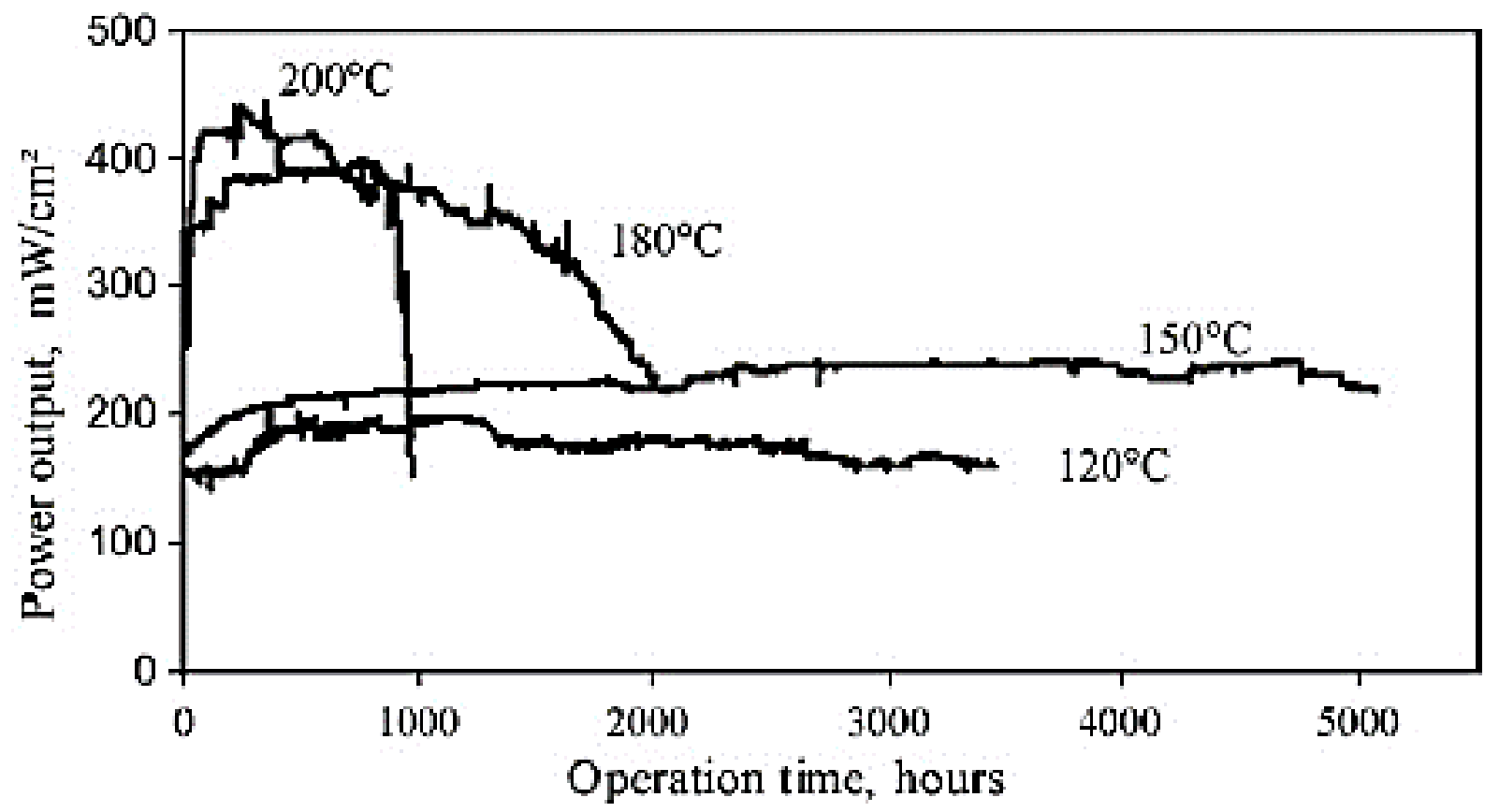

Figure 12. Lifetime test of a PBI cell under continuous operation at different temperatures with hydrogen and oxygen at ambient pressure. Reproduced from [228], Elsevier: 2009.

It has been reported that for the commercialization of the fuel cells, the fabrication costs and lifetime should be decreased and increased, respectively, by a factor of two [229]. According to the predictions commissioned by the Carbon Trust in the UK, large-scale fabrication of the current PEMFC technology will cost about $\$ 49 \mathrm{~kW}^{-1}$ in automotive applications. This cost should be reduced to about $\$ 36 \mathrm{~kW}^{-1}$ in order to compete with the internal combustion engines $[230,231]$. This reduction in capital costs can be achieved by improving conductivity/power density, chemical stability, and durability and reducing materials costs and system complexity. In order to reduce the manufacturing costs, several aspects of materials selection should be taken into account, such as manufacturing costs, durability, etc. The mechanical strength of the membrane is of the most important factors in choosing the appropriate material.

The pressure and flow rate of the fuel and the oxidant should be optimized in order to reduce the operation costs, especially when the fuel is hydrogen [232]. Other factors such as the distribution of reactant gases in a cell can also affect the current density and cell overall performance [233]. Therefore, future investigations should be inclined toward reducing the fabrication costs and improving the cell durability and mechanical strength of PEMFCs at high temperatures.

\subsection{Economic Viability and the Prospect of HT-PEM Fuel Cells}

Working at a higher temperature (between 150 and $180^{\circ} \mathrm{C}$ ) is associated with advantages over the low-temperature range $[117,134]$. The operation at higher temperatures could enable the PEM fuel cells (a) to operate with the reforming fuels (obtained from the internal/external reforming units integrated with HT-PEM fuel cells) with less sensitivity to fuel impurities such as carbon monoxide and hydrogen sulphide; (b) to alleviate the water management issues, and (c) to regenerate the excessive heat of the associated electrochemical reactions by integrating a heat-recovery system to the fuel cell as the main consequences $[112,228,234]$. It is also worth mentioning that raising the operating temperature could bring some challenges such as (a) more severe materials and cell component degradation (including membranes, catalysts, support, etc.); (b) slow start-up and shutdown procedures; (c) lower performance, especially when a Nafion-based membrane is used; and (d) more complexity by the introduction of fuel reformers, heat-recovery 
system, cooler, etc.; which all require more precise controls to obtain efficient and reliable performance out of the fabricated HT-PEM stacks [16,112].

\subsection{Advanced Application and Future Research Direction}

Based on the characteristics mentioned above, the HT-PEM fuel cell could be promising for two major applications: (a) in transportation as a main or auxiliary power unit (APU) [228] and (b) in micro-CHP (combined heat and power) units [235]. Due to its tolerance to impurities in the fuel, the HT-PEM fuel cell is suitable for application in APU with great versatility over various fuels such as natural gas (NG), reforming-based syngas, and liquefied petroleum gases (LPG) [235]. In other words, adding up the servicing units such as a reforming facility, a water managing system, and a heat-recovery system can result in gaining a more compact system design, allowing various industrial applications such as CHP units for the residential and commercial applications, and even for more diverse applications such as industrial heating/cooling systems, aviation, space crafts, etc. $[28,36,227]$. PEMFCs have recently been used in aeronautic applications such as silent operations, where they can reduce the noise generated in the airports and help personnel who are inadvertently working under such conditions [236]. Recently, PEMFCs have been used to fabricate portable and wearable fuel cells for soldier use [237]. Other noncommercialized applications such as unmanned aerial vehicles (UAV), e-bikes, trains, etc., have been under development and may be commercialized in the near future [238].

For distribution into the market, a comparative study of a fuel cell-based system is crucial. A fuel cell vehicle should meet the same standards as what has been offered by the internal combustion engine in terms of supporting a fast cold start and the availability of power without compromising the space available for the user under any foreseeable conditions $[36,239]$. The power density of a complete fuel cell system must be $650 \mathrm{~W} \cdot \mathrm{L}^{-1}$ (almost equivalent to $650 \mathrm{~W} . \mathrm{kg}^{-1}$ ), which means it should offer about $2000 \mathrm{~W} . \mathrm{L}^{-1}$ (or $2000 \mathrm{~W} . \mathrm{kg}^{-1}$ ) when it is integrated into a fuel cell stack [36]. The main stationary applications of HT-PEM fuel cells include buildings such as houses, hypermarkets, schools, hotels, hospitals, data centres, and industrial users such as chemical plants, refineries, and distribution utilities. Due to the availability of pipeline natural gas, economic considerations (both electricity and gas prices), the opportunity for possible energy savings by customers, and the impact of such savings on the world energy consumption, CHP systems, etc., can tap into these markets $[36,43,240]$.

Like any energy application, the primary driver for acceptance of the fuel-cell-based power generation systems is their payback period (which is typically taken as 3-5 years in the energy sector). The payback period for a fuel cell system is a function of (a) the initial system cost, i.e., the capital cost of the stack and its elements, fuel processor, inverter, the balance of plant components (BoP), heat exchangers, power units, integration and assembly of these components, as well as the factory acceptance test, and (b) the life cycle (operating) cost which is mainly dictated by the efficiency of the system, cost of fuel, servicing and maintenance fees, etc. [43]. Other factors such as the grid congestion and unreliability, global warming, urbanisation, rising energy costs, ability to use waste heat, and avoidance of peak load constraints do also play roles in the decision making of the market [43,241-243]. Fuel cells for the CHP applications need to be $\sim 80-90 \%$ efficient, cost effective (less than $\$ 2000 \mathrm{~kW}^{-1}$ per installed unit), have useable heat (about $150-250{ }^{\circ} \mathrm{C}$ ), and a long life duration (at least 10 years) to meet the required prerequisites to enter into the energy market [194,244].

Despite the developments in fuel cell technology, its introduction into markets still suffers from many challenges, including the competitive costs, reasonable lifetime, durability, high performance, and durable products (MEA, bipolar plates, and BoP). Nowadays, the most widely commercialized fuel cell system in the CHP market is the LT-PEM fuel cell system entered as "Ene-Farm", which is a kind of cogeneration home fuel cell system. The power output of the LT-PEM fuel cell system is about $0.75 \mathrm{~kW}$ with a lifetime of $60 \mathrm{kh}[36,235]$. 
Over the last decade, impressive activities have been conducted by both the research and manufacturing communities to reduce the costs of PEM fuel cells to become more competitive for commercial use. It is well accepted that large-scale production lowers the manufacturing cost of the cell components and leads to a lower stack cost. The increase in yearly production rate from 10 to $50 \mathrm{k}$ units can decrease the cost of a CHP system to about one-third per unit [235]. In order to meet the target cost of $\$ 1000 \mathrm{~kW}^{-1}$, the material cost of each component still needs to be further reduced. The material cost of MEAs is mainly determined by the catalyst, membrane, and GDL. In an LT-PEM fuel cell, the membrane is the most expensive component in a stack ( $27 \%$ of the total stack cost) [245]. The cost of membranes is, however, less critical for HT-PEM fuel cells because of using the low material cost of PA-doped PBI membranes, which is estimated to be less than $5 € . \mathrm{m}^{-2}$ at 100 g.m ${ }^{-2}$ of the area-specific weight and is about $50 \%$ of the cost of the perfluorinated Nafion, which is estimated to be $5-10 € . \mathrm{m}^{-2}$ at $100 \mathrm{~g} \cdot \mathrm{m}^{-2}$ [246]. On the other hand, the catalyst cost becomes more critical in determining the HT-PEM fuel cell stack cost because of the major contribution by the Pt content of the cell that is necessary to generate comparable electrical output. Due to the high cost of catalysts, the stack for HT-PEM fuel cells is more expensive than that of LT-PEM fuel cells. However, it becomes competitive at the system level because of its more compact system design [245].

As discussed earlier, a fuel cell experiences a gradual decline in power output due to exposure to a very aggressive and harsh environment (i.e., severe reducing and oxidizing situations with water, acids, and radicals, also subjected to high electrochemical potentials and temperatures), which influence its durability. Thus, if the stack durability can be established, the HT-PEM fuel cell is expected to exhibit higher durability at the system level.

Technical targets have been established for commercializing PEM fuel cells as electrical power sources for transportation and stationary applications. Although these targets are almost developed for LT-PEM fuel cells, they are, due to their formulation, partly relevant for HT-PEM fuel cells. Compared to the LT-PEM fuel cell systems, the HT-PEM fuel cell systems contain fewer components and are less sensitive to fuel impurity [28]. However, due to high-operating-temperature effects and also the presence of PA in the MEA, establishing a durability target is more challenging for HT-PEM fuel cells compared to LT-PEM fuel cells at the stack level [36].

The required durability target of HT-PEM fuel cell systems differs for transportation and CHP applications [245]. For the transportation application, the systems need to satisfy the durability target of $20 \mathrm{kh}$ with a degradation rate of $1 \% / 1 \mathrm{kh}$. The APU systems should work under some specific conditions, such as in the mode of weekly cycles to off state and daily cycles to stand-by conditions. A lifetime of about $60 \mathrm{kh}$ is expected to reach by 2020 for a micro-CHP with power in the range of 1 to $10 \mathrm{~kW}$. Another target, where the start-up/shutdown cycles occur no more than once in a month and with a total of fewer than 100 on-off cycles, is to reach the degradation rate of about $0.3 \% / 1 \mathrm{kh}$ [36].

\section{Conclusions}

This article provides a review of the current status, operating principles, and recent advances of high-temperature polymer electrolyte membranes (HT-PEMs) with a particular focus on the recent developments, economic viability, technical challenges, and commercial prospects of the HT-PEM fuel cells. Specific consideration has been paid to proton conductivity and fuel cell performance of PA-PBI-based membranes. In recent decades, the HT-PEMs fuel cell operation has attracted a lot of attention due to its higher CO tolerance, faster electrode reaction kinetics, use of a lower amount of precious metals, easier heat and water management, and high performance. As a result of the recognised high proton conductivity after PA doping, PBI has been known to be an HT-PEM for application in HT-PEM fuel cells. For developing the PA-PBI based membranes as an alternative to commercial Nafion membrane, several critical issues that need to be addressed in the future include: (1) reducing the fuel permeability; (2) improving the acid retention (or reducing the PA leakage); (3) understanding the mechanisms of proton transport through 
the membrane; and (4) optimizing the sandwiched membrane structure that enables high conductivity, high PA retention, and high fuel cell performance.

Author Contributions: Writing-original draft preparation, K.H., B.A.H. and H.A.; conceptualization, writing-review, editing, and supervision, M.F.V. and B.A.H.; investigation, resources, and data curation, P.K. and P.S.; project administration, B.A.H. All authors have read and agreed to the published version of the manuscript.

Funding: This research received no external funding.

Institutional Review Board Statement: Not applicable.

Informed Consent Statement: Not applicable.

Data Availability Statement: Please refer to suggested Data Availability Statements in section “MDPI Research Data Policies" at https://www.mdpi.com/ethics.

Conflicts of Interest: The authors declare no conflict of interest.

\section{References}

1. Song, C.; Lee, S.; Gu, B.; Chang, I.; Cho, G.Y.; Baek, J.D.; Cha, S.W. A Study of Anode-Supported Solid Oxide Fuel Cell Modeling and Optimization Using Neural Network and Multi-Armed Bandit Algorithm. Energies 2020, 13, 1621. [CrossRef]

2. Wang, Y.; Ruiz Diaz, D.F.; Chen, K.S.; Wang, Z.; Adroher, X.C. Materials, technological status, and fundamentals of PEM fuel cells-A review. Mater. Today 2020, 32, 178-203. [CrossRef]

3. Vostakola, M.F.; Horri, B.A. Progress in Material Development for Low-Temperature Solid Oxide Fuel Cells: A Review. Energies 2021, 14, 1280. [CrossRef]

4. Hou, J.; Yang, M.; Wang, D.; Zhang, J. Fundamentals and Challenges of Lithium Ion Batteries at Temperatures between -40 and $60{ }^{\circ} \mathrm{C}$. Adv. Energy Mater. 2020, 10, 1904152. [CrossRef]

5. Zhang, H.; Sun, C. Cost-effective iron-based aqueous redox flow batteries for large-scale energy storage application: A review. J. Power Sources 2021, 493, 229445. [CrossRef]

6. Doetsch, C.; Pohlig, A. The Use of Flow Batteries in Storing Electricity for National Grids; Elsevier Ltd.: Oxford, UK, 2020; ISBN 9780081028865.

7. Clemente, A.; Costa-Castelló, R. Redox flow batteries: A literature review oriented to automatic control. Energies 2020, 13, 4514. [CrossRef]

8. Shri Prakash, B.; Pavitra, R.; Senthil Kumar, S.; Aruna, S.T. Electrolyte bi-layering strategy to improve the performance of an intermediate temperature solid oxide fuel cell: A review. J. Power Sources 2018, 381, 136-155. [CrossRef]

9. Da Silva, F.S.; de Souza, T.M. Novel materials for solid oxide fuel cell technologies: A literature review. Int. J. Hydrogen Energy 2017, 42, 26020-26036. [CrossRef]

10. Karimi, M.B.; Mohammadi, F.; Hooshyari, K. Non-humidified fuel cells using a deep eutectic solvent (DES) as the electrolyte within a polymer electrolyte membrane (PEM): The effect of water and counterions. Phys. Chem. Chem. Phys. 2020, 22, $2917-2929$. [CrossRef] [PubMed]

11. Beydaghi, H.; Bagheri, A.; Salarizadeh, P.; Kashefi, S.; Hooshyari, K.; Amoozadeh, A.; Shamsi, T.; Bonaccorso, F.; Pellegrini, V. Enhancing the Performance of Poly(phthalazinone ether ketone)-Based Membranes Using a New Type of Functionalized TiO 2 with Superior Proton Conductivity. Ind. Eng. Chem. Res. 2020, 59, 6589-6599. [CrossRef]

12. Kumar, A.; Hong, J.-W.; Yun, Y.; Bhardwaj, A.; Song, S.-J. The role of surface lattice defects of $\mathrm{CeO}_{2-\delta}$ nanoparticles as a scavenging redox catalyst in polymer electrolyte membrane fuel cells. J. Mater. Chem. A 2020, 8, 26023-26034. [CrossRef]

13. Hooshyari, K.; Javanbakht, M.; Salarizadeh, P.; Bageri, A. Advanced nanocomposite membranes based on sulfonated polyethersulfone: Influence of nanoparticles on PEMFC performance. J. Iran. Chem. Soc. 2019, 16, 1617-1629. [CrossRef]

14. Jayakumar, A. An Assessment on Polymer Electrolyte Membrane Fuel Cell Stack Components. In Applied Physical Chemistry with Multidisciplinary Approaches; Haghi, A.K., Balköse, D., Thomas, S., Eds.; Apple Academic Press Inc.: Oakville, ON, Canada, 2018; pp. 23-49, ISBN 9781771886062.

15. Beydaghi, H.; Javanbakht, M.; Bagheri, A.; Ghafarian-Zahmatkesh, H.; Hooshyari, K. Preparation and Characterization of Electrocatalyst Nanoparticles for Direct Methanol Fuel Cell Applications Using $\beta$-D-glucose as Protection Agent. Iran. J. Hydrog. Fuel Cell 2017, 4, 1-11. [CrossRef]

16. Jannelli, E.; Minutillo, M.; Perna, A. Analyzing microcogeneration systems based on LT-PEMFC and HT-PEMFC by energy balances. Appl. Energy 2013, 108, 82-91. [CrossRef]

17. Ma, K.B.; Kwak, D.H.; Han, S.B.; Park, H.S.; Kim, D.H.; Won, J.E.; Kwon, S.H.; Kim, M.C.; Moon, S.H.; Park, K.W. Direct Ethanol Fuel Cells with Superior Ethanol-Tolerant Nonprecious Metal Cathode Catalysts for Oxygen Reduction Reaction. ACS Sustain. Chem. Eng. 2018, 6, 7609-7618. [CrossRef]

18. Velayutham, P.; Sahu, A.K.; Parthasarathy, S. A Nafion-ceria composite membrane electrolyte for reduced methanol crossover in direct methanol fuel cells. Energies 2017, 10, 259. [CrossRef] 
19. Van Eck, N.J.; Waltman, L. Software survey: VOSviewer, a computer program for bibliometric mapping. Scientometrics 2010, 84, 523-538. [CrossRef]

20. Van Eck, N.J.; Waltman, L. VOSviewer Manual; Univeristeit Leiden: Leiden, The Netherlands, 2013.

21. Zhou, Z.; Zholobko, O.; Wu, X.-F.; Aulich, T.; Thakare, J.; Hurley, J. Polybenzimidazole-Based Polymer Electrolyte Membranes for High-Temperature Fuel Cells: Current Status and Prospects. Energies 2020, 14, 135. [CrossRef]

22. Moradi, M.; Moheb, A.; Javanbakht, M.; Hooshyari, K. Experimental study and modeling of proton conductivity of phosphoric acid doped $\mathrm{PBI}-\mathrm{Fe}_{2} \mathrm{TiO}_{5}$ nanocomposite membranes for using in high temperature proton exchange membrane fuel cell (HTPEMFC). Int. J. Hydrogen Energy 2016, 41, 2896-2910. [CrossRef]

23. Tian, D.; Gu, T.; Yellamilli, S.N.; Bae, C. Phosphoric acid-doped ion-pair coordinated PEMs with broad relative humidity tolerance. Energies 2020, 13, 1924. [CrossRef]

24. Üregen, N.; Pehlivanoğlu, K.; Özdemir, Y.; Devrim, Y. Development of polybenzimidazole/graphene oxide composite membranes for high temperature PEM fuel cells. Int. J. Hydrogen Energy 2017, 42, 2636-2647. [CrossRef]

25. Attaran, A.M. Fabrication and Characterization of Poly Vinyl Alcohol/ Poly Vinyl Pyrrolidone/ $\mathrm{MnTiO}_{3} \mathrm{Nanocomposite}$ Membranes for PEM Fuel Cells. Iran. J. Energy Environ. 2013, 4, 86-90. [CrossRef]

26. Salarizadeh, P.; Askari, M.B.; Mohammadi, M.; Hooshyari, K. Electrocatalytic performance of $\mathrm{CeO}_{2}$-decorated rGO as an anode electrocatalyst for the methanol oxidation reaction. J. Phys. Chem. Solids 2020, 142, 109442. [CrossRef]

27. Li, X.; Wang, P.; Liu, Z.; Peng, J.; Shi, C.; Hu, W.; Jiang, Z.; Liu, B. Arylether-type polybenzimidazoles bearing benzimidazolyl pendants for high-temperature proton exchange membrane fuel cells. J. Power Sources 2018, 393, 99-107. [CrossRef]

28. Haider, R.; Wen, Y.; Ma, Z.F.; Wilkinson, D.P.; Zhang, L.; Yuan, X.; Song, S.; Zhang, J. High temperature proton exchange membrane fuel cells: Progress in advanced materials and key technologies. Chem. Soc. Rev. 2021, 50, 1138-1187. [CrossRef] [PubMed]

29. Lee, S.; Seo, K.; Ghorpade, R.V.; Nam, K.H.; Han, H. High temperature anhydrous proton exchange membranes based on chemically-functionalized titanium/polybenzimidazole composites for fuel cells. Mater. Lett. 2020, 263, 127167. [CrossRef]

30. Berber, M.R.; Nakashima, N. Bipyridine-based polybenzimidazole membranes with outstanding hydrogen fuel cell performance at high temperature and non-humidifying conditions. J. Memb. Sci. 2019, 591, 117354. [CrossRef]

31. Hosseinabadi, P.; Hooshyari, K.; Javanbakht, M.; Enhessari, M. Synthesis and optimization of nanocomposite membranes based on SPEEK and perovskite nanoparticles for polymer electrolyte membrane fuel cells. New J. Chem. 2019, 43, 16232-16245. [CrossRef]

32. Salarizadeh, P.; Javanbakht, M.; Pourmahdian, S.; Hazer, M.S.A.; Hooshyari, K.; Askari, M.B. Novel proton exchange membranes based on proton conductive sulfonated PAMPS/PSSA- $\mathrm{TiO}_{2}$ hybrid nanoparticles and sulfonated poly (ether ether ketone) for PEMFC. Int. J. Hydrogen Energy 2019, 44, 3099-3114. [CrossRef]

33. Hooshyari, K.; Javanbakht, M.; Enhessari, M.; Beydaghi, H. Novel PVA/ $\mathrm{La}_{2} \mathrm{Ce}_{2} \mathrm{O}_{7}$ hybrid nanocomposite membranes for application in proton exchange membrane fuel cells. Iran. J. Hydrog. Fuel Cell Iran. J. Hydrog. Fuel Cell IJHFC J. 2014, 2, 105-112.

34. Attaran, A.M.; Javanbakht, M.; Hooshyari, K.; Enhessari, M. New proton conducting nanocomposite membranes based on poly vinyl alcohol/poly vinyl pyrrolidone/ $\mathrm{BaZrO}_{3}$ for proton exchange membrane fuel cells. Solid State Ionics 2015, 269, 98-105. [CrossRef]

35. Sun, X.; Simonsen, S.C.; Norby, T.; Chatzitakis, A. Composite membranes for high temperature PEM fuel cells and electrolysers: A critical review. Membranes 2019, 9, 83. [CrossRef]

36. Jakobsen, M.T.D.; Jensen, J.O.; Cleemann, L.N.; Li, Q. Durability Issues and Status of PBI-Based Fuel Cells. In High Temperature Polymer Electrolyte Membrane Fuel Cells. Approaches, Status, and Perspectives; Li, Q., Aili, D., Hjuler, H.A., Jensen, J.O., Eds.; Springer International Publishing: Cham, Switzerland, 2016; pp. 487-509, ISBN 9783319170824.

37. Leykin, A.Y.; Askadskii, A.A.; Vasilev, V.G.; Rusanov, A.L. Dependence of some properties of phosphoric acid doped PBIs on their chemical structure. J. Memb. Sci. 2010, 347, 69-74. [CrossRef]

38. Kang, Y.; Zou, J.; Sun, Z.; Wang, F.; Zhu, H.; Han, K.; Yang, W.; Song, H.; Meng, Q. Polybenzimidazole containing ether units as electrolyte for high temperature proton exchange membrane fuel cells. Int. J. Hydrogen Energy 2013, 38, 6494-6502. [CrossRef]

39. Farrokhi, M.; Abdollahi, M. Enhancing medium/high temperature proton conductivity of poly(benzimidazole)-based proton exchange membrane via blending with poly(vinyl imidazole-co-vinyl phosphonic acid) copolymer: Proton conductivity-copolymer microstructure relationship. Eur. Polym. J. 2020, 131, 109691. [CrossRef]

40. Bouchet, R.; Siebert, E. Proton conduction in acid doped polybenzimidazole. Solid State Ionics 1999, 118, 287-299. [CrossRef]

41. Luo, H.; Vaivars, G.; Agboola, B.; Mu, S.; Mathe, M. Anion exchange membrane based on alkali doped poly (2,5-benzimidazole) for fuel cell. Solid State Ionics 2012, 208, 52-55. [CrossRef]

42. Lin, A.J.; Yan, X.; He, G.; Chen, W.; Zhen, D.; Li, T.; Ma, L.; Wu, X. Thermoplastic interpenetrating polymer networks based on polybenzimidazole and poly (1, 2-dimethy-3-allylimidazolium) for anion exchange membranes. Electrochim. Acta 2017, 257, 9-19. [CrossRef]

43. Fuel Cells and Hydrogen Production a Volume in the Encyclopedia of Sustainability Science and Technology, 2nd ed.; Lipman, T.E.; Weber, A.Z. (Eds.) Springer: Berkeley, CA, USA, 2019; ISBN 9781493977888.

44. Escorihuela, J.; García-Bernabé, A.; Compañ, V. A deep insight into different acidic additives as doping agents for enhancing proton conductivity on polybenzimidazole membranes. Polymers 2020, 12, 1374. [CrossRef] [PubMed] 
45. Schechter, A.; Savinell, R.F. Imidazole and 1-methyl imidazole in phosphoric acid doped polybenzimidazole, electrolyte for fuel cells. Solid State Ionics 2002, 147, 181-187. [CrossRef]

46. Li, Q.; He, R.; Berg, R.W.; Hjuler, H.A.; Bjerrum, N.J. Water uptake and acid doping of polybenzimidazoles as electrolyte membranes for fuel cells. Solid State Ionics 2004, 168, 177-185. [CrossRef]

47. He, R.; Li, Q.; Xiao, G.; Bjerrum, N.J. Proton conductivity of phosphoric acid doped polybenzimidazole and its composites with inorganic proton conductors. J. Memb. Sci. 2003, 226, 169-184. [CrossRef]

48. Mader, J.A.; Benicewicz, B.C. Sulfonated polybenzimidazoles for high temperature PEM fuel cells. Macromolecules 2010, 43, 6706-6715. [CrossRef]

49. Li, X.; Ma, H.; Wang, P.; Liu, Z.; Peng, J.; Hu, W.; Jiang, Z.; Liu, B.; Guiver, M.D. Highly Conductive and Mechanically Stable Imidazole-Rich Cross-Linked Networks for High-Temperature Proton Exchange Membrane Fuel Cells. Chem. Mater. 2020, 32, 1182-1191. [CrossRef]

50. Jones, D.J.; Rozière, J. Recent advances in the functionalisation of polybenzimidazole and polyetherketone for fuel cell applications. J. Memb. Sci. 2001, 185, 41-58. [CrossRef]

51. Asensio, J.A.; Sánchez, E.M.; Romero, P.G. Proton-conducting membranes based on benzimidazole polymers for high-temperature PEM fuel cells. A chemical quest. Chem. Soc. Rev. 2010, 39, 3210-3239. [CrossRef]

52. Zaidi, S.M.J.; Mikhailenko, S.D.; Robertson, G.P.; Guiver, M.D.; Kaliaguine, S. Proton conducting composite membranes from polyether ether ketone and heteropolyacids for fuel cell applications. J. Memb. Sci. 2000, 173, 17-34. [CrossRef]

53. Park, K.T.; Jung, U.H.; Choi, D.W.; Chun, K.; Lee, H.M.; Kim, S.H. $\mathrm{ZrO}_{2}-\mathrm{SiO}_{2} / \mathrm{Nafion}^{\circledR}$ composite membrane for polymer electrolyte membrane fuel cells operation at high temperature and low humidity. J. Power Sources 2008, 177, 247-253. [CrossRef]

54. Hooshyari, K.; Khanamiri, S.N.; Salarizadeh, P.; Beydaghi, H. Nanocomposite Membranes with High Fuel Cell Performance Based on Sulfonated Poly (1,4-phenylene ether ether sulfone) and Ytterbium/Yttrium Doped-Perovskite Nanoparticles. J. Electrochem. Soc. 2019, 166, F976-F989. [CrossRef]

55. Berber, M.R.; Nakashima, N. Tailoring Different Molecular Weight Phenylene-Polybenzimidazole Membranes with Remarkable Oxidative Stability and Conductive Properties for Higherature Polymer Electrolyte Fuel Cells. ACS Appl. Mater. Interfaces 2019, 11, 46269-46277. [CrossRef] [PubMed]

56. Berber, M.R. Molecular Weight Impact of Poly(2,5-Benzimidazole) Polymer on Film Conductivity, Ion Exchange Capacity, Acid Retention Capability, and Oxidative Stability. Front. Energy Res. 2020, 8, 1-11. [CrossRef]

57. Yang, J.S.; Cleemann, L.N.; Steenberg, T.; Terkelsen, C.; Li, Q.F.; Jensen, J.O.; Hjuler, H.A.; Bjerrum, N.J.; He, R.H. High molecular weight polybenzimidazole membranes for high temperature PEMFC. Fuel Cells 2014, 14, 7-15. [CrossRef]

58. Schaffer, J.V.; Lupatini, K.N.; Machado, B.; Silva, E.S.; Ferracin, R.J.; Alves, H.J. Parameters effect on proton conductivity to obtain chitosan membranes for use as electrolytes in PEMFC. Int. J. Energy Res. 2018, 42, 1381-1385. [CrossRef]

59. Gagliardi, G.G.; Ibrahim, A.; Borello, D.; El-Kharouf, A. Composite polymers development and application for polymer electrolyte membrane technologies-A review. Molecules 2020, 25, 1712. [CrossRef]

60. Adjemian, K.T.; Dominey, R.; Krishnan, L.; Ota, H.; Majsztrik, P.; Zhang, T.; Mann, J.; Kirby, B.; Gatto, L.; Velo-Simpson, M.; et al.

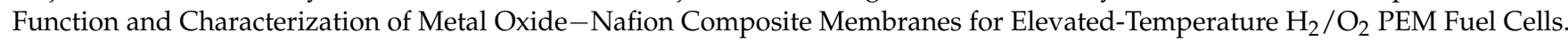
Chem. Mater. 2006, 18, 2238-2248. [CrossRef]

61. Wei, Y.; Qian, T.; Liu, J.; Guo, X.; Gong, Q.; Liu, Z.; Tian, B.; Qiao, J. Novel composite Nafion membranes modified with copper phthalocyanine tetrasulfonic acid tetrasodium salt for fuel cell application. J. Mater. 2019, 5, 252-257. [CrossRef]

62. Muthuraja, P.; Prakash, S.; Shanmugam, V.M.; Radhakrsihnan, S.; Manisankar, P. Novel perovskite structured calcium titanate-PBI composite membranes for high-temperature PEM fuel cells: Synthesis and characterizations. Int. J. Hydrogen Energy 2018, 43, 4763-4772. [CrossRef]

63. Ioana-Maria, N.; Aurora, J.; Victoria, C.; Cristian, B. Advanced polymeric materials based on PBI/SiO 2 composite with highperformances designated for PEM-fuel cells. In Proceedings of the 2017 Electric Vehicles International Conference, Bucharest, Romania, 5-6 October 2017; pp. 1-6.

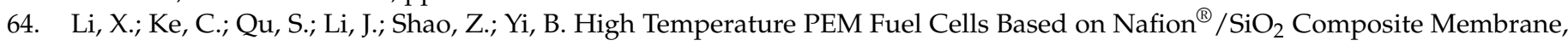
Energy Storage in the Emerging Era of Smart Grids. In Energy Storage in the Emerging Era of Smart Grids; Carbone, R., Ed.; IntechOpen: Reggio Calabria, Italy, 2011; pp. 279-298. ISBN 978-953-307-269-2.

65. He, Y.; Wang, D.; Li, Q.; Huang, L.; Bao, H. Composite Polymer Electrolyte Membranes based on Nafion and Modified PVDF Electrospun Nanofiber Mats. J. Wuhan Univ. Technol. Mater. Sci. Ed. 2020, 35, 677-681. [CrossRef]

66. Yang, J.; Shen, P.K.; Varcoe, J.; Wei, Z. Nafion/polyaniline composite membranes specifically designed to allow proton exchange membrane fuel cells operation at low humidity. J. Power Sources 2009, 189, 1016-1019. [CrossRef]

67. Trogadas, P.; Parrondo, J.; Ramani, V. Degradation mitigation in polymer electrolyte membranes using cerium oxide as a regenerative free-radical scavenger. Electrochem. Solid-State Lett. 2008, 11, 113-116. [CrossRef]

68. Di Noto, V.; Boaretto, N.; Negro, E.; Pace, G. New inorganic-organic proton conducting membranes based on Nafion and hydrophobic fluoroalkylated silica nanoparticles. J. Power Sources 2010, 195, 7734-7742. [CrossRef]

69. Giffin, G.A.; Piga, M.; Lavina, S.; Navarra, M.A.; D’Epifanio, A.; Scrosati, B.; Noto, V. Di Characterization of sulfatedzirconia/Nafion ${ }^{\circledR}$ composite membranes for proton exchange membrane fuel cells. J. Power Sources 2012, 198, 66-75. [CrossRef]

70. Saccà, A.; Gatto, I.; Carbone, A.; Pedicini, R.; Passalacqua, E. $\mathrm{ZrO}_{2}$-Nafion composite membranes for polymer electrolyte fuel cells (PEFCs) at intermediate temperature. J. Power Sources 2006, 163, 47-51. [CrossRef] 
71. He, D.; Tang, H.; Kou, Z.; Pan, M.; Sun, X.; Zhang, J.; Mu, S. Engineered Graphene Materials: Synthesis and Applications for Polymer Electrolyte Membrane Fuel Cells. Adv. Mater. 2017, 29, 1601741. [CrossRef]

72. Bakangura, E.; Wu, L.; Ge, L.; Yang, Z.; Xu, T. Mixed matrix proton exchange membranes for fuel cells: State of the art and perspectives. Prog. Polym. Sci. 2016, 57, 103-152. [CrossRef]

73. Escorihuela, J.; Narducci, R.; Compañ, V.; Costantino, F. Proton Conductivity of Composite Polyelectrolyte Membranes with Metal-Organic Frameworks for Fuel Cell Applications. Adv. Mater. Interfaces 2019, 6, 1801146. [CrossRef]

74. Bhattacharjee, S.; Chen, C.; Ahn, W.S. Chromium terephthalate metal-organic framework MIL-101: Synthesis, functionalization, and applications for adsorption and catalysis. RSC Adv. 2014, 4, 52500-52525. [CrossRef]

75. Anahidzade, N.; Abdolmaleki, A.; Dinari, M.; Firouz Tadavani, K.; Zhiani, M. Metal-organic framework anchored sulfonated poly(ether sulfone) as a high temperature proton exchange membrane for fuel cells. J. Memb. Sci. 2018, 565, 281-292. [CrossRef]

76. Liu, Q.; Li, Z.; Wang, D.; Li, Z.; Peng, X.; Liu, C.; Zheng, P. Metal Organic Frameworks Modified Proton Exchange Membranes for Fuel Cells. Front. Chem. 2020, 8, 694. [CrossRef]

77. Kitao, T.; Zhang, Y.; Kitagawa, S.; Wang, B.; Uemura, T. Hybridization of MOFs and polymers. Chem. Soc. Rev. 2017, 46, 3108-3133. [CrossRef]

78. Rao, Z.; Feng, K.; Tang, B.; Wu, P. Construction of well interconnected metal-organic framework structure for effectively promoting proton conductivity of proton exchange membrane. J. Memb. Sci. 2017, 533, 160-170. [CrossRef]

79. Donnadio, A.; Narducci, R.; Casciola, M.; Marmottini, F.; D’Amato, R.; Jazestani, M.; Chiniforoshan, H.; Costantino, F. Mixed Membrane Matrices Based on Nafion/UiO-66/SO 3 H-UiO-66 Nano-MOFs: Revealing the Effect of Crystal Size, Sulfonation, and Filler Loading on the Mechanical and Conductivity Properties. ACS Appl. Mater. Interfaces 2017, 9, 42239-42246. [CrossRef] [PubMed]

80. Yang, Q.; Wiersum, A.D.; Llewellyn, P.L.; Guillerm, V.; Serre, C.; Maurin, G. Functionalizing porous zirconium terephthalate UiO-66(Zr) for natural gas upgrading: A computational exploration. Chem. Commun. 2011, 47, 9603-9605. [CrossRef] [PubMed]

81. DeStefano, M.R.; Islamoglu, T.; Garibay, S.J.; Hupp, J.T.; Farha, O.K. Room Temperature Synthesis of UiO-66 and Thermal Modulation of Densities of Defect Sites. Chem. Mater. 2017, 29, 1357-1361. [CrossRef]

82. Patel, H.A.; Mansor, N.; Gadipelli, S.; Brett, D.J.L.; Guo, Z. Superacidity in Nafion/MOF Hybrid Membranes Retains Water at Low Humidity to Enhance Proton Conduction for Fuel Cells. ACS Appl. Mater. Interfaces 2016, 8, 30687-30691. [CrossRef]

83. Rao, Z.; Tang, B.; Wu, P. Proton Conductivity of Proton Exchange Membrane Synergistically Promoted by Different Functionalized Metal-Organic Frameworks. ACS Appl. Mater. Interfaces 2017, 9, 22597-22603. [CrossRef]

84. Liu, Q.; Li, Y.; Zheng, L.; Shang, J.; Liu, X.; Yu, R.; Shui, J. Sequential Synthesis and Active-Site Coordination Principle of Precious Metal Single-Atom Catalysts for Oxygen Reduction Reaction and PEM Fuel Cells. Adv. Energy Mater. 2020, 10, 2000689. [CrossRef]

85. Liang, X.; Zhang, F.; Feng, W.; Zou, X.; Zhao, C.; Na, H.; Liu, C.; Sun, F.; Zhu, G. From metal-organic framework (MOF) to MOF-polymer composite membrane: Enhancement of low-humidity proton conductivity. Chem. Sci. 2013, 4, 983-992. [CrossRef]

86. Horike, S.; Umeyama, D.; Inukai, M.; Itakura, T.; Kitagawa, S. Coordination-network-based ionic plastic crystal for anhydrous proton conductivity. J. Am. Chem. Soc. 2012, 134, 7612-7615. [CrossRef] [PubMed]

87. Gao, C.; Chen, J.; Zhang, B.; Wang, L. Effect of chemical structure and degree of branching on the stability of proton exchange membranes based on sulfonated polynaphthylimides. Polymers 2020, 12, 652. [CrossRef]

88. Iwamoto, N. A property trend study of polybenzimidazole using molecular modeling. Polym. Eng. Sci. 1994, 34, 434-437. [CrossRef]

89. Sun, R.; Xia, Z.; Yang, C.; Jing, F.; Wang, S.; Sun, G. Experimental measurement of proton conductivity and electronic conductivity of membrane electrode assembly for proton exchange membrane fuel cells. Prog. Nat. Sci. Mater. Int. 2020, 30, 912-917. [CrossRef]

90. Sana, B.; Koyilapu, R.; Dineshkumar, S.; Muthusamy, A.; Jana, T. High temperature PEMs developed from the blends of Polybenzimidazole and poly(azomethine-ether). J. Polym. Res. 2019, 26. [CrossRef]

91. Aaron, D.; Yiacoumi, S.; Tsouris, C. Effects of proton-exchange membrane fuel-cell operating conditions on charge transfer resistances measured by electrochemical impedance spectroscopy. Sep. Sci. Technol. 2008, 43, 2307-2320. [CrossRef]

92. Paul, D.K.; McCreery, R.; Karan, K. Proton Transport Property in Supported Nafion Nanothin Films by Electrochemical Impedance Spectroscopy. J. Electrochem. Soc. 2014, 161, F1395-F1402. [CrossRef]

93. Escorihuela, J.; Olvera-Mancilla, J.; Alexandrova, L.; del Castillo, L.F.; Compañ, V. Recent progress in the development of composite membranes based on polybenzimidazole for high temperature proton exchange membrane (PEM) fuel cell applications. Polymers 2020, 12, 1861. [CrossRef]

94. Li, Q.; Yin, Q.; Zheng, Y.S.; Sui, Z.J.; Zhou, X.G.; Chen, D.; Zhu, Y.A. Insights into Hydrogen Transport Behavior on Perovskite Surfaces: Transition from the Grotthuss Mechanism to the Vehicle Mechanism. Langmuir 2019, 35, 9962-9969. [CrossRef]

95. Luduena, G.A.; Kuhne, T.D.; Sebastiani, D. Comment on "Mixed Grotthuss and vehicle transport mechanism in proton conducting polymers from Ab initio molecular dynamics simulations". Chem. Mater. 2011, 23, 1424-1429. [CrossRef]

96. Singha, S.; Koyilapu, R.; Dana, K.; Jana, T. Polybenzimidazole-Clay Nanocomposite Membrane for PEM fuel cell: Effect of organomodifier structure. Polymer 2019, 167, 13-20. [CrossRef]

97. Zhang, H.; Wu, W.; Wang, J.; Zhang, T.; Shi, B.; Liu, J.; Cao, S. Enhanced anhydrous proton conductivity of polymer electrolyte membrane enabled by facile ionic liquid-based hoping pathways. J. Memb. Sci. 2015, 476, 136-147. [CrossRef]

98. Liu, Z.; Tsou, Y.M.; Calundann, G.; De Castro, E. New process for high temperature polybenzimidazole membrane production and its impact on the membrane and the membrane electrode assembly. J. Power Sources 2011, 196, 1055-1060. [CrossRef] 
99. Kim, D.J.; Jo, M.J.; Nam, S.Y. A review of polymer-nanocomposite electrolyte membranes for fuel cell application. J. Ind. Eng. Chem. 2015, 21, 36-52. [CrossRef]

100. Hogarth, W.H.J.; Diniz Da Costa, J.C.; Lu, G.Q. Solid acid membranes for high temperature $\left(>140^{\circ} \mathrm{C}\right)$ proton exchange membrane fuel cells. J. Power Sources 2005, 142, 223-237. [CrossRef]

101. Lafitte, B.; Jannasch, P. On the Prospects for Phosphonated Polymers as Proton-Exchange Fuel Cell Membranes. In Advances in Fuel Cells; Kreuer, K.-D., Van Nguyen, T., Eds.; Elsevier: Lund, Sweden, 2007; Volume 1, pp. 119-185. ISBN 9780080453941.

102. Kreuer, K.D.; Paddison, S.J.; Spohr, E.; Schuster, M. Transport in proton conductors for fuel-cell applications: Simulations, elementary reactions, and phenomenology. Chem. Rev. 2004, 104, 4637-4678. [CrossRef] [PubMed]

103. Zuo, Z.; Fu, Y.; Manthiram, A. Novel blend membranes based on acid-base interactions for fuel cells. Polymers 2012, 4, 1627-1644 [CrossRef]

104. Yamada, M.; Honma, I. Anhydrous proton conducting polymer electrolytes based on poly(vinylphosphonic acid)-heterocycle composite material. Polymer 2005, 46, 2986-2992. [CrossRef]

105. Fontanella, J.J.; Wintersgill, M.C.; Wainright, J.S.; Savinell, R.F.; Litt, M. High pressure electrical conductivity studies of acid doped polybenzimidazole. Electrochim. Acta 1998, 43, 1289-1294. [CrossRef]

106. Fu, Y.-Z.; Manthiram, A. Nafion-Imidazole- $\mathrm{H}_{3} \mathrm{PO}_{4}$ Composite Membranes for Proton Exchange Membrane Fuel Cells. J. Electrochem. Soc. 2007, 154, B8. [CrossRef]

107. Jung, H.Y.; Park, J.K. Blend membranes based on sulfonated poly(ether ether ketone) and poly(vinylidene fluoride) for high performance direct methanol fuel cell. Electrochim. Acta 2007, 52, 7464-7468. [CrossRef]

108. Du, C.; Zhao, B.; Chen, X.B.; Birbilis, N.; Yang, H. Effect of water presence on choline chloride-2urea ionic liquid and coating platings from the hydrated ionic liquid. Sci. Rep. 2016, 6, 1-14. [CrossRef]

109. Pei, P.; Wang, M.; Chen, D.; Ren, P.; Zhang, L. Key technologies for polymer electrolyte membrane fuel cell systems fueled impure hydrogen. Prog. Nat. Sci. Mater. Int. 2020, 30, 751-763. [CrossRef]

110. Schenk, A.; Cermenek, B.; Hacker, V. Other polymer electrolyte fuel cells. In Fuel Cells and Hydrogen: From Fundamentals to Applied Research; Elsevier Inc.: Amsterdam, The Netherlands, 2018; pp. 91-115. ISBN 9780128114599.

111. Wan, Z.; Chang, H.; Shu, S.; Wang, Y.; Tang, H. A review on cold start of proton exchange membrane fuel cells. Energies 2014, 7, 3179-3203. [CrossRef]

112. Rosli, R.E.; Sulong, A.B.; Daud, W.R.W.; Zulkifley, M.A.; Husaini, T.; Rosli, M.I.; Majlan, E.H.; Haque, M.A. A review of high-temperature proton exchange membrane fuel cell (HT-PEMFC) system. Int. J. Hydrogen Energy 2017, 42, 9293-9314. [CrossRef]

113. Yang, C.; Costamagna, P.; Srinivasan, S.; Benziger, J.; Bocarsly, A.B. Approaches and technical challenges to high temperature operation of proton exchange membrane fuel cells. J. Power Sources 2001, 103, 1-9. [CrossRef]

114. Haque, M.A.; Sulong, A.B.; Loh, K.S.; Majlan, E.H.; Husaini, T.; Rosli, R.E. Acid doped polybenzimidazoles based membrane electrode assembly for high temperature proton exchange membrane fuel cell: A review. Int. J. Hydrogen Energy 2017, 42, 9156-9179. [CrossRef]

115. Branco, C.M.; El-kharouf, A.; Du, S. Materials for Polymer Electrolyte Membrane Fuel Cells (PEMFCs): Electrolyte Membrane, Gas Diffusion Layers and Bipolar Plates; Elsevier Ltd.: Amsterdam, The Netherlands, 2020; ISBN 9780128157329.

116. Soltanimehr, S.; Rezaei, F.; Rahimpour, M.R. Impact assessment of exhaust gas emissions from cogeneration PEMFC systems. In Current Trends and Future Developments on (Bio-) Membranes; Elsevier: Amsterdam, The Netherlands, 2020; pp. 49-64, ISBN 9780128178072.

117. Chandan, A.; Hattenberger, M.; El-Kharouf, A.; Du, S.; Dhir, A.; Self, V.; Pollet, B.G.; Ingram, A.; Bujalski, W. High temperature (HT) polymer electrolyte membrane fuel cells (PEMFC)-A review. J. Power Sources 2013, 231, 264-278. [CrossRef]

118. Hooshyari, K.; Javanbakht, M.; Adibi, M. Novel composite membranes based on PBI and dicationic ionic liquids for high temperature polymer electrolyte membrane fuel cells. Electrochim. Acta 2016, 205, 142-152. [CrossRef]

119. Karimi, M.B.; Mohammadi, F.; Hooshyari, K. Recent approaches to improve Nafion performance for fuel cell applications: A review. Int. J. Hydrogen Energy 2019, 44, 28919-28938. [CrossRef]

120. Reimer, U.; Ehlert, J.; Janßen, H.; Lehnert, W. Water distribution in high temperature polymer electrolyte fuel cells. Int. J. Hydrogen Energy 2016, 41, 1837-1845. [CrossRef]

121. Salarizadeh, P.; Bagheri, A.; Beydaghi, H.; Hooshyari, K. Enhanced properties of SPEEK with incorporating of PFSA and barium strontium titanate nanoparticles for application in DMFCs. Int. J. Energy Res. 2019, 43, 4840-4853. [CrossRef]

122. Karimi, M.B.; Mohammadi, F.; Hooshyari, K. Effect of deep eutectic solvents hydrogen bond acceptor on the anhydrous proton conductivity of Nafion membrane for fuel cell applications. J. Memb. Sci. 2020, 605, 118116. [CrossRef]

123. Hooshyari, K.; Javanbakht, M.; Naji, L.; Enhessari, M. Nanocomposite proton exchange membranes based on Nafion containing Fe2TiO5 nanoparticles in water and alcohol environments for PEMFC. J. Memb. Sci. 2014, 454, 74-81. [CrossRef]

124. Karimi, M.B.; Mohammadi, F.; Hooshyari, K. Potential use of deep eutectic solvents (DESs) to enhance anhydrous proton conductivity of Nafion $115^{\circledR}$ membrane for fuel cell applications. J. Memb. Sci. 2020, 611, 118217. [CrossRef]

125. Wang, P.; Liu, Z.; Li, X.; Peng, J.; Hu, W.; Liu, B. Toward enhanced conductivity of high-temperature proton exchange membranes: Development of novel PIM-1 reinforced PBI alloy membranes. Chem. Commun. 2019, 55, 6491-6494. [CrossRef] 
126. Krishnan, N.N.; Lee, S.; Ghorpade, R.V.; Konovalova, A.; Jang, J.H.; Kim, H.J.; Han, J.; Henkensmeier, D.; Han, H. Polybenzimidazole (PBI-OO) based composite membranes using sulfophenylated $\mathrm{TiO}_{2}$ as both filler and crosslinker, and their use in the HT-PEM fuel cell. J. Memb. Sci. 2018, 560, 11-20. [CrossRef]

127. Shabanikia, A.; Javanbakht, M.; Amoli, H.S.; Hooshyari, K.; Enhessari, M. Novel nanocomposite membranes based on polybenzimidazole and $\mathrm{Fe}_{2} \mathrm{TiO}_{5}$ nanoparticles for proton exchange membrane fuel cells. Ionics 2015, 21, 2227-2236. [CrossRef]

128. Shabanikia, A.; Javanbakht, M.; Amoli, H.S.; Hooshyari, K.; Enhessari, M. Polybenzimidazole/strontium cerate nanocomposites with enhanced proton conductivity for proton exchange membrane fuel cells operating at high temperature. Electrochim. Acta 2015, 154, 370-378. [CrossRef]

129. Chen, J.C.; Hsiao, Y.R.; Liu, Y.C.; Chen, P.Y.; Chen, K.H. Polybenzimidazoles containing heterocyclic benzo[c]cinnoline structure prepared by sol-gel process and acid doping level adjustment for high temperature PEMFC application. Polymer 2019, 182, 121814. [CrossRef]

130. Hooshyari, K.; Rezania, H.; Vatanpour, V.; Salarizadeh, P.; Askari, M.B.; Beydaghi, H.; Enhessari, M. High temperature membranes based on PBI/sulfonated polyimide and doped-perovskite nanoparticles for PEM fuel cells. J. Memb. Sci. 2020, 612, 118436. [CrossRef]

131. Ogawa, T.; Kamiguchi, K.; Tamaki, T.; Imai, H.; Yamaguchi, T. Differentiating Grotthuss proton conduction mechanisms by nuclear magnetic resonance spectroscopic analysis of frozen samples. Anal. Chem. 2014, 86, 9362-9366. [CrossRef]

132. Asadi Tashvigh, A.; Luo, L.; Chung, T.S.; Weber, M.; Maletzko, C. Performance enhancement in organic solvent nanofiltration by double crosslinking technique using sulfonated polyphenylsulfone (sPPSU) and polybenzimidazole (PBI). J. Memb. Sci. 2018, 551, 204-213. [CrossRef]

133. Araya, S.S.; Zhou, F.; Liso, V.; Sahlin, S.L.; Vang, J.R.; Thomas, S.; Gao, X.; Jeppesen, C.; Kær, S.K. A comprehensive review of PBI-based high temperature PEM fuel cells. Int. J. Hydrogen Energy 2016, 41, 21310-21344. [CrossRef]

134. Bose, S.; Kuila, T.; Nguyen, T.X.H.; Kim, N.H.; Lau, K.T.; Lee, J.H. Polymer membranes for high temperature proton exchange membrane fuel cell: Recent advances and challenges. Prog. Polym. Sci. 2011, 36, 813-843. [CrossRef]

135. Hooshyari, K.; Javanbakht, M.; Shabanikia, A.; Enhessari, M. Fabrication BaZrO3/PBI-based nanocomposite as a new proton conducting membrane for high temperature proton exchange membrane fuel cells. J. Power Sources 2015, 276, 62-72. [CrossRef]

136. Vilčiauskas, L.; Tuckerman, M.E.; Bester, G.; Paddison, S.J.; Kreuer, K.D. The mechanism of proton conduction in phosphoric acid. Nat. Chem. 2012, 4, 461-466. [CrossRef] [PubMed]

137. Park, H.; Kim, H.; Kim, D.K.; Lee, W.J.; Choi, I.; Kim, H.J.; Kim, S.K. Performance deterioration and recovery in high-temperature polymer electrolyte membrane fuel cells: Effects of deliquescence of phosphoric acid. Int. J. Hydrogen Energy 2020, 45, 32844-32855. [CrossRef]

138. Korte, C.; Conti, F.; Wackerl, J.; Lehnert, W. Phosphoric acid and its interactions with polybenzimidazole-type Polymers. In High Temperature Polymer Electrolyte Membrane Fuel Cells; Springer: Cham, Switzerland, 2016; pp. 169-194. ISBN 9783319170824.

139. Maity, S.; Singha, S.; Jana, T. Low acid leaching PEM for fuel cell based on polybenzimidazole nanocomposites with protic ionic liquid modified silica. Polymer 2015, 66, 76-85. [CrossRef]

140. Sana, B.; Jana, T. Polybenzimidazole composite with acidic surfactant like molecules: A unique approach to develop PEM for fuel cell. Eur. Polym. J. 2016, 84, 421-434. [CrossRef]

141. Rajabi, Z.; Javanbakht, M.; Hooshyari, K.; Badiei, A.; Adibi, M. High temperature composite membranes based on polybenzimidazole and dendrimer amine functionalized SBA-15 mesoporous silica for fuel cells. New J. Chem. 2020, 44, 5001-5018. [CrossRef]

142. Hooshyari, K.; Javanbakht, M.; Adibi, M. Novel composite membranes based on dicationic ionic liquid and polybenzimidazole mixtures as strategy for enhancing thermal and electrochemical properties of proton exchange membrane fuel cells applications at high temperature. Int. J. Hydrogen Energy 2016, 41, 10870-10883. [CrossRef]

143. Hooshyari, K.; Moradi, M.; Salarizadeh, P. Novel nanocomposite membranes based on PBI and doped-perovskite nanoparticles as a strategy for improving PEMFC performance at high temperatures. Int. J. Energy Res. 2020, 44, 2617-2633. [CrossRef]

144. Ma, Y.-L.; Wainright, J.S.; Litt, M.H.; Savinell, R.F. Conductivity of PBI Membranes for High-Temperature Polymer Electrolyte Fuel Cells. J. Electrochem. Soc. 2004, 151, A8. [CrossRef]

145. Guan, Y.; Pu, H.; Jin, M.; Chang, Z.; Modestov, A.D. Proton conducting membranes based on poly $\left(2,2^{\prime}\right.$-imidazole-5,5'bibenzimidazole). Fuel Cells 2012, 12, 124-131. [CrossRef]

146. Molleo, M.A.; Chen, X.; Ploehn, H.J.; Fishel, K.J.; Benicewicz, B.C. High Polymer Content 3,5-Pyridine-Polybenzimidazole Copolymer Membranes with Improved Compressive Properties. Fuel Cells 2014, 14, 16-25. [CrossRef]

147. Kumar, B.S.; Sana, B.; Unnikrishnan, G.; Jana, T.; Kumar, K.S.S. Polybenzimidazole co-polymers: Their synthesis, morphology and high temperature fuel cell membrane properties. Polym. Chem. 2020, 11, 1043-1054. [CrossRef]

148. Pingitore, A.T.; Huang, F.; Qian, G.; Benicewicz, B.C. Durable High Polymer Content m/p-Polybenzimidazole Membranes for Extended Lifetime Electrochemical Devices. ACS Appl. Energy Mater. 2019, 2, 1720-1726. [CrossRef]

149. Jahangiri, S.; Aravi, İ.; Işıkel Şanlı, L.; Menceloğlu, Y.Z.; Özden-Yenigün, E. Fabrication and optimization of proton conductive polybenzimidazole electrospun nanofiber membranes. Polym. Adv. Technol. 2018, 29, 594-602. [CrossRef]

150. Joseph, D.; Krishnan, N.N.; Henkensmeier, D.; Jang, J.H.; Choi, S.H.; Kim, H.J.; Han, J.; Nam, S.W. Thermal crosslinking of PBI/sulfonated polysulfone based blend membranes. J. Mater. Chem. A 2017, 5, 409-417. [CrossRef] 
151. Mader, J.A.; Benicewicz, B.C. Synthesis and properties of segmented block copolymers of functionalised polybenzimidazoles for high-temperature pem fuel cells. Fuel Cells 2011, 11, 222-237. [CrossRef]

152. Huang, F.; Pingitore, A.T.; Benicewicz, B.C. Electrochemical Hydrogen Separation from Reformate Using High-Temperature Polybenzimidazole (PBI) Membranes: The Role of Chemistry. ACS Sustain. Chem. Eng. 2020, 8, 6234-6242. [CrossRef]

153. Hooshyari, K.; Heydari, S.; Javanbakht, M.; Beydaghi, H.; Enhessari, M. Fabrication and performance evaluation of new nanocomposite membranes based on sulfonated poly(phthalazinone ether ketone) for PEM fuel cells. RSC Adv. 2020, 10, 2709-2721. [CrossRef]

154. Li, X.; Ma, H.; Shen, Y.; Hu, W.; Jiang, Z.; Liu, B.; Guiver, M.D. Dimensionally-stable phosphoric acid-doped polybenzimidazoles for high-temperature proton exchange membrane fuel cells. J. Power Sources 2016, 336, 391-400. [CrossRef]

155. Ishihara, T. (Ed.) Perovskite Oxide for Solid Oxide Fuel Cells Fuel Cells and Hydrogen Energy; Springer: Dordrecht, The Netherlands, 2009; ISBN 9780387777078.

156. Dunne, P.W.; Starkey, C.L.; Munn, A.S.; Tang, S.V.Y.; Luebben, O.; Shvets, I.; Ryder, A.G.; Casamayou-Boucau, Y.; Morrison, L.; Lester, E.H. Bench- and pilot-scale continuous-flow hydrothermal production of barium strontium titanate nanopowders. Chem. Eng. J. 2016, 289, 433-441. [CrossRef]

157. Yuan, S.; Guo, X.; Aili, D.; Pan, C.; Li, Q.; Fang, J. Poly(imide benzimidazole)s for high temperature polymer electrolyte membrane fuel cells. J. Memb. Sci. 2014, 454, 351-358. [CrossRef]

158. Maity, S.; Jana, T. Polybenzimidazole block copolymers for fuel cell: Synthesis and studies of block length effects on nanophase separation, mechanical properties, and proton conductivity of PEM. ACS Appl. Mater. Interfaces 2014, 6, 6851-6864. [CrossRef]

159. Wang, L.; Wu, Y.; Fang, M.; Chen, J.; Liu, X.; Yin, B.; Wang, L. Synthesis and preparation of branched block polybenzimidazole membranes with high proton conductivity and single-cell performance for use in high temperature proton exchange membrane fuel cells. J. Memb. Sci. 2020, 602, 117981. [CrossRef]

160. Suda, T.; Yamazaki, K.; Kawakami, H. Syntheses of sulfonated star-hyperbranched polyimides and their proton exchange membrane properties. J. Power Sources 2010, 195, 4641-4646. [CrossRef]

161. Pan, H.; Chen, S.; Jin, M.; Chang, Z.; Pu, H. Preparation and properties of sulfonated polybenzimidazole-polyimide block copolymers as electrolyte membranes. Ionics 2018, 24, 1629-1638. [CrossRef]

162. Skorikova, G.; Rauber, D.; Aili, D.; Martin, S.; Li, Q.; Henkensmeier, D.; Hempelmann, R. Protic ionic liquids immobilized in phosphoric acid-doped polybenzimidazole matrix enable polymer electrolyte fuel cell operation at $200{ }^{\circ} \mathrm{C}$. J. Memb. Sci. 2020, 608, 118188. [CrossRef]

163. Chen, D.; Chen, X.; Ding, L.; Li, X. Advanced acid-base blend ion exchange membranes with high performance for vanadium flow battery application. J. Memb. Sci. 2018, 553, 25-31. [CrossRef]

164. Nagamani, C.; Versek, C.; Thorn, M.; Tuominen, M.T.; Thayumanavan, S. Proton conduction in 1H-1,2,3-triazole polymers: Imidazole-like or pyrazole-like? J. Polym. Sci. Part A Polym. Chem. 2010, 48, 1851-1858. [CrossRef]

165. Ghomari, K.; Boukoussa, B.; Hamacha, R.; Bengueddach, A.; Roy, R.; Azzouz, A. Preparation of dendrimer polyol/mesoporous silica nanocomposite for reversible $\mathrm{CO}_{2}$ adsorption: Effect of pore size and polyol content. Sep. Sci. Technol. 2017, 52, 2421-2428. [CrossRef]

166. Mishra, A.K.; Kim, N.H.; Lee, J.H. Effects of ionic liquid-functionalized mesoporous silica on the proton conductivity of acid-doped poly(2,5-benzimidazole) composite membranes for high-temperature fuel cells. J. Memb. Sci. 2014, 449, 136-145. [CrossRef]

167. Bouazizi, N.; Louhichi, S.; Ouargli, R.; Bargougui, R.; Vieillard, J.; Le Derf, F.; Azzouz, A. Cuo-loaded SBA-15@ZnO with improved electrical properties and affinity towards hydrogen. Appl. Surf. Sci. 2017, 404, 146-153. [CrossRef]

168. Imran, M.A.; He, G.; Wu, X.; Yan, X.; Li, T.; Khan, A.S. Fabrication and characterization of sulfonated polybenzimidazole/sulfonated imidized graphene oxide hybrid membranes for high temperature proton exchange membrane fuel cells. J. Appl. Polym. Sci. 2019, 136, 1-13. [CrossRef]

169. Sun, C.; Zlotorowicz, A.; Nawn, G.; Negro, E.; Bertasi, F.; Pagot, G.; Vezzù, K.; Pace, G.; Guarnieri, M.; Di, V. [Nafion/(WO3)x] hybrid membranes for vanadium redox flow batteries. Solid State Ionics 2018, 319, 110-116. [CrossRef]

170. Cai, Y.; Yue, Z.; Xu, S. A novel polybenzimidazole composite modified by sulfonated graphene oxide for high temperature proton exchange membrane fuel cells in anhydrous atmosphere. J. Appl. Polym. Sci. 2017, 134, 44986. [CrossRef]

171. Nambi Krishnan, N.; Konovalova, A.; Aili, D.; Li, Q.; Park, H.S.; Jang, J.H.; Kim, H.J.; Henkensmeier, D. Thermally crosslinked sulfonated polybenzimidazole membranes and their performance in high temperature polymer electrolyte fuel cells. J. Memb. Sci. 2019, 588, 117218. [CrossRef]

172. Wang, S.; Sun, P.; Li, Z.; Liu, G.; Yin, X. Comprehensive performance enhancement of polybenzimidazole based high temperature proton exchange membranes by doping with a novel intercalated proton conductor. Int. J. Hydrogen Energy 2018, 43, 9994-10003. [CrossRef]

173. Sun, P.; Li, Z.; Jin, L.; Yang, Y.; Wang, S.; Yin, X.; Wang, Y. Pre-Oxidized Acrylic Fiber Reinforced Ferric Sulfophenyl PhosphateDoped Polybenzimidazole-Based High-Temperature Proton Exchange Membrane. Macromol. Mater. Eng. 2017, $302,1600468$. [CrossRef]

174. Escorihuela, J.; García-Bernabé, A.; Montero, Á.; Sahuquillo, Ó.; Giménez, E.; Compañ, V. Ionic liquid composite polybenzimidazol membranes for high temperature PEMFC applications. Polymers 2019, 11, 732. [CrossRef] [PubMed] 
175. Seo, K.; Seo, J.; Nam, K.-H.; Han, H. Polybenzimidazole/Inorganic Composite Membrane with Advanced Performance for High Temperature Polymer Electrolyte Membrane Fuel Cells. Polym. Polym. Compos. 2017, 38, 87-95. [CrossRef]

176. Zhang, Q.; Liu, H.; Li, X.; Xu, R.; Zhong, J.; Chen, R.; Gu, X. Synthesis and characterization of polybenzimidazole/ $\alpha$-zirconium phosphate composites as proton exchange membrane. Polym. Eng. Sci. 2016, 56, 622-628. [CrossRef]

177. Cheng, Y.; Zhang, J.; Lu, S.; Kuang, H.; Bradley, J.; De Marco, R.; Aili, D.; Li, Q.; Cui, C.Q.; Jiang, S.P. High CO tolerance of new $\mathrm{SiO}_{2}$ doped phosphoric acid/polybenzimidazole polymer electrolyte membrane fuel cells at high temperatures of $200-250{ }^{\circ} \mathrm{C}$. Int. J. Hydrogen Energy 2018, 22487-22499. [CrossRef]

178. Yang, J.; Liu, C.; Gao, L.; Wang, J.; Xu, Y.; He, R. Novel composite membranes of triazole modified graphene oxide and polybenzimidazole for high temperature polymer electrolyte membrane fuel cell applications. RSC Adv. 2015, 5, 101049-101054. [CrossRef]

179. Yang, J.; Gao, L.; Wang, J.; Xu, Y.; Liu, C.; He, R. Strengthening Phosphoric Acid Doped Polybenzimidazole Membranes with Siloxane Networks for Using as High Temperature Proton Exchange Membranes. Macromol. Chem. Phys. 2017, 218, 1-10. [CrossRef]

180. Yang, J.; Aili, D.; Li, Q.; Cleemann, L.N.; Jensen, J.O.; Bjerrum, N.J.; He, R. Covalently cross-linked sulfone polybenzimidazole membranes with poly(vinylbenzyl chloride) for fuel cell applications. ChemSusChem 2013, 6, 275-282. [CrossRef]

181. Chen, H.; Wang, S.; Liu, F.; Wang, D.; Li, J.; Mao, T.; Liu, G.; Wang, X.; Xu, J.; Wang, Z. Base-acid doped polybenzimidazole with high phosphoric acid retention for HT-PEMFC applications. J. Memb. Sci. 2020, 596, 117722. [CrossRef]

182. Eguizábal, A.; Lemus, J.; Roda, V.; Urbiztondo, M.; Barreras, F.; Pina, M.P. Nanostructured electrolyte membranes based on zeotypes, protic ionic liquids and porous PBI membranes: Preparation, characterization and MEA testing. Int. J. Hydrogen Energy 2012, 37, 7221-7234. [CrossRef]

183. Özdemir, Y.; Üregen, N.; Devrim, Y. Polybenzimidazole based nanocomposite membranes with enhanced proton conductivity for high temperature PEM fuel cells. Int. J. Hydrogen Energy 2017, 42, 2648-2657. [CrossRef]

184. Aili, D.; Allward, T.; Alfaro, S.M.; Hartmann-Thompson, C.; Steenberg, T.; Hjuler, H.A.; Li, Q.; Jensen, J.O.; Stark, E.J. Polybenzimidazole and sulfonated polyhedral oligosilsesquioxane composite membranes for high temperature polymer electrolyte membrane fuel cells. Electrochim. Acta 2014, 140, 182-190. [CrossRef]

185. Barati, S.; Abdollahi, M.; Mehdipourghazi, M.; Khoshandam, B. High temperature proton exchange porous membranes based on polybenzimidazole/ lignosulfonate blends: Preparation, morphology and physical and proton conductivity properties. Int. J. Hydrogen Energy 2019, 44, 30440-30453. [CrossRef]

186. Barati, S.; Abdollahi, M.; Khoshandam, B.; Mehdipourghazi, M. Highly proton conductive porous membranes based on polybenzimidazole/ lignin blends for high temperatures proton exchange membranes: Preparation, characterization and morphology- proton conductivity relationship. Int. J. Hydrogen Energy 2018, 43, 19681-19690. [CrossRef]

187. Hazarika, M.; Jana, T. Novel proton exchange membrane for fuel cell developed from blends of polybenzimidazole with fluorinated polymer. Eur. Polym. J. 2013, 49, 1564-1576. [CrossRef]

188. Li, Q.; Pan, C.; Jensen, J.O.; Noye, P.; Bjerrum, N.J. Cross-Linked Polybenzimidazole Membranes for Fuel Cells. Chem. Mater. 2007, 19, 350-352. [CrossRef]

189. Chang, Z.; Pu, H.; Wan, D.; Liu, L.; Yuan, J.; Yang, Z. Chemical oxidative degradation of Polybenzimidazole in simulated environment of fuel cells. Polym. Degrad. Stab. 2009, 94, 1206-1212. [CrossRef]

190. LaConti, A.B.; Liu, H.; Mittelsteadt, C.; McDonald, R.C. Polymer Electrolyte Membrane Degradation Mechanisms in Fuel Cells-Findings Over the Past 30 Years and Comparison with Electrolyzers. ECS Trans. 2006, 1, 199-219. [CrossRef]

191. Samms, S.R.; Wasmus, S.; Savinell, R.F. Thermal Stability of Proton Conducting Acid Doped Polybenzimidazole in Simulated Fuel Cell Environments. J. Electrochem. Soc. 1996, 143, 1225-1232. [CrossRef]

192. Jaffe, M.; Haider, M.I.; Menczel, J.; Rafalko, J. Thermal characterization of high performance PBI and 6F polymers and their alloys. Polym. Eng. Sci. 1992, 32, 1236-1241. [CrossRef]

193. Wang, J.T.; Savinell, R.F.; Wainright, J.; Litt, M.; Yu, H. A $\mathrm{H}_{2} / \mathrm{O}_{2}$ fuel cell using acid doped polybenzimidazole as polymer electrolyte. Electrochim. Acta 1996, 41, 193-197. [CrossRef]

194. Borup, R.; Meyers, J.; Pivovar, B.; Kim, Y.S.; Mukundan, R.; Garland, N.; Myers, D.; Wilson, M.; Garzon, F.; Wood, D.; et al. Scientific aspects of polymer electrolyte fuel cell durability and degradation. Chem. Rev. 2007, 107, 3904-3951. [CrossRef]

195. Yousfi-Steiner, N.; Moçotéguy, P.; Candusso, D.; Hissel, D. A review on polymer electrolyte membrane fuel cell catalyst degradation and starvation issues: Causes, consequences and diagnostic for mitigation. J. Power Sources 2009, 194, 130-145. [CrossRef]

196. Akita, T.; Taniguchi, A.; Maekawa, J.; Siroma, Z.; Tanaka, K.; Kohyama, M.; Yasuda, K. Analytical TEM study of Pt particle depositiaon in the proton-exchange membrane of a membrane-electrode-assembly. J. Power Sources 2006, 159, 461-467. [CrossRef]

197. Cui, Y.; Wu, Y.; Wang, Z.; Yao, X.; Wei, Y.; Kang, Y. Mitigating Metal Dissolution and Redeposition of Pt-Co Catalysts in PEM Fuel Cells: Impacts of Structural Ordering and Particle Size Mitigating Metal Dissolution and Redeposition of Pt-Co Catalysts in PEM Fuel Cells: Impacts of Structural Ordering and P. J. Electrochem. Soc. 2020, 167, 064520. [CrossRef]

198. Borup, R.L.; Davey, J.R.; Garzon, F.H.; Wood, D.L.; Inbody, M.A. PEM fuel cell electrocatalyst durability measurements. J. Power Sources 2006, 163, 76-81. [CrossRef]

199. Zhai, Y.; Zhang, H.; Xing, D.; Shao, Z.G. The stability of Pt/C catalyst in $\mathrm{H}_{3} \mathrm{PO}_{4} / \mathrm{PBI}$ PEMFC during high temperature life test. J. Power Sources 2007, 164, 126-133. [CrossRef] 
200. Galbiati, S.; Baricci, A.; Casalegno, A.; Marchesi, R. Degradation in phosphoric acid doped polymer fuel cells: A $6000 \mathrm{~h}$ parametric investigation. Int. J. Hydrogen Energy 2013, 38, 6469-6480. [CrossRef]

201. Schmidt, T.J.; Baurmeister, J. Properties of high-temperature PEFC Celtec ${ }^{\circledR}$-P 1000 MEAs in start/stop operation mode. J. Power Sources 2008, 176, 428-434. [CrossRef]

202. Hartnig, C.; Schmidt, T.J. Simulated start-stop as a rapid aging tool for polymer electrolyte fuel cell electrodes. J. Power Sources 2011, 196, 5564-5572. [CrossRef]

203. Mack, F.; Heissler, S.; Laukenmann, R.; Zeis, R. Phosphoric acid distribution and its impact on the performance of polybenzimidazole membranes. J. Power Sources 2014, 270, 627-633. [CrossRef]

204. Zhang, C.; Li, W.; Hu, M.; Cheng, X.; He, K.; Mao, L. A Comparative Study of Using Polarization Curve Models in Proton Exchange Membrane Fuel Cell Degradation Analysis. Energies 2020, 13, 3759. [CrossRef]

205. Bharath, K.V.S.; Blaabjerg, F.; Haque, A.; Khan, M.A. Model-based data driven approach for fault identification in proton exchange membrane fuel cell. Energies 2020, 13, 3144. [CrossRef]

206. Lee, K.S.; Lee, B.S.; Yoo, S.J.; Kim, S.K.; Hwang, S.J.; Kim, H.J.; Cho, E.; Henkensmeier, D.; Yun, J.W.; Nam, S.W.; et al. Development of a galvanostatic analysis technique as an in-situ diagnostic tool for PEMFC single cells and stacks. Int. J. Hydrogen Energy 2012, 37, 5891-5900. [CrossRef]

207. Najafi, B.; Bonomi, P.; Casalegno, A.; Rinaldi, F.; Baricci, A. Rapid fault diagnosis of PEM fuel cells through optimal electrochemical impedance spectroscopy tests. Energies 2020, 13, 3643. [CrossRef]

208. Wang, H.; Macomber, C.; Christ, J.; Bender, G.; Pivovar, B.; Dinh, H.N. Evaluating the Influence of PEMFC System Contaminants on the Performance of Pt Catalyst via Cyclic Voltammetry. Electrocatalysis 2014, 5, 62-67. [CrossRef]

209. Dobbelaere, T.; Vereecken, P.M.; Detavernier, C. A USB-controlled potentiostat/galvanostat for thin-film battery characterization. HardwareX 2017, 2, 34-49. [CrossRef]

210. Araya, S.S.; Andreasen, S.J.; Kær, S.K. Parametric sensitivity tests-european polymer electrolyte membrane fuel cell stack test procedures. J. Fuel Cell Sci. Technol. 2014, 11, 061007. [CrossRef]

211. Pilinski, N.; Rastedt, M.; Wagner, P. Investigation of Phosphoric Acid Distribution in PBI based HT-PEM Fuel Cells. ECS Trans. 2015, 69, 323-335. [CrossRef]

212. Oono, Y.; Sounai, A.; Hori, M. Long-term cell degradation mechanism in high-temperature proton exchange membrane fuel cells. J. Power Sources 2012, 210, 366-373. [CrossRef]

213. Rangel-Cárdenas, A.L.; Koper, G.J.M. Transport in Proton Exchange Membranes for Fuel Cell Applications-A Systematic Non-Equilibrium Approach. Materials 2017, 10, 576. [CrossRef]

214. Fang, J.H. Polyimide proton exchange membranes. In Advanced Polyimide Materials: Synthesis, Characterization, and Applications; Yang, S.-Y., Ed.; Elsevier Inc.: Beijing, China, 2018; pp. 323-383. ISBN 9780128126400.

215. Selyanchyn, O.; Selyanchyn, R.; Lyth, S.M. A Review of Proton Conductivity in Cellulosic Materials. Front. Energy Res. 2020, 8 , 596164. [CrossRef]

216. Heimerdinger, P.; Rosin, A.; Danzer, M.A.; Gerdes, T. A novel method for humidity-dependent through-plane impedance measurement for proton conducting polymer membranes. Membranes 2019, 9, 62. [CrossRef] [PubMed]

217. Cooper, K. Characterizing Through-Plane and In-Plane Ionic Conductivity of Polymer Electrolyte Membranes. ECS Trans. 2011, 41, 1371-1380. [CrossRef]

218. Gardner, C.L.; Anantaraman, A.V. Studies on ion-exchange membranes. II. Measurement of the anisotropic conductance of Nafion ${ }^{\circledR}$. J. Electroanal. Chem. 1998, 449, 209-214. [CrossRef]

219. Alberti, G.; Casciola, M.; Massinelli, L.; Bauer, B. Polymeric proton conducting membranes for medium temperature fuel cells (110-160 ㄷ). J. Memb. Sci. 2001, 185, 73-81. [CrossRef]

220. Xie, Z.; Song, C.; Andreaus, B.; Navessin, T.; Shi, Z.; Zhang, J.; Holdcroft, S. Discrepancies in the Measurement of Ionic Conductivity of PEMs Using Two- and Four-Probe AC Impedance Spectroscopy. J. Electrochem. Soc. 2006, 153, E173. [CrossRef]

221. Ma, S.; Siroma, Z.; Tanaka, H. Anisotropic Conductivity over In-Plane and Thickness Directions in Nafion-117. J. Electrochem. Soc. 2006, 153, A2274. [CrossRef]

222. Dippel, T.; Kreuer, K.D.; Lassègues, J.C.; Rodriguez, D. Proton conductivity in fused phosphoric acid; a 1H/31P PFG-NMR and QNS study. Solid State Ionics 1993, 61, 41-46. [CrossRef]

223. Wannek, C.; Kohnen, B.; Oetjen, H.F.; Lippert, H.; Mergel, J. Durability of ABPBI-based MEAs for high temperature PEMFCs at different operating conditions. Fuel Cells 2008, 8, 87-95. [CrossRef]

224. Oono, Y.; Sounai, A.; Hori, M. Influence of the phosphoric acid-doping level in a polybenzimidazole membrane on the cell performance of high-temperature proton exchange membrane fuel cells. J. Power Sources 2009, 189, 943-949. [CrossRef]

225. Tian, X.; Wang, S.; Li, J.; Liu, F.; Wang, X.; Chen, H.; Wang, D.; Ni, H.; Wang, Z. Benzimidazole grafted polybenzimidazole cross-linked membranes with excellent PA stability for high-temperature proton exchange membrane applications. Appl. Surf. Sci. 2019, 465, 332-339. [CrossRef]

226. He, R.; Li, Q.; Bach, A.; Jensen, J.O.; Bjerrum, N.J. Physicochemical properties of phosphoric acid doped polybenzimidazole membranes for fuel cells. J. Memb. Sci. 2006, 277, 38-45. [CrossRef]

227. Garland, N.; Benjamin, T.; Kopasz, J. DOE Fuel Cell Program: Durability Technical Targets and Testing Protocols. ECS Trans. 2019, 11, 923-931. [CrossRef] 
228. Li, Q.; Jensen, J.O.; Savinell, R.F.; Bjerrum, N.J. High temperature proton exchange membranes based on polybenzimidazoles for fuel cells. Prog. Polym. Sci. 2009, 34, 449-477. [CrossRef]

229. Greene, D.L. Status and Outlook for the U.S. Non-Automotive Fuel Cell Industry: Impacts of Government Policies and Assessment of Future Opportunities; Oak Ridge National Laboratory: Oak Ridge, TN, USA, 2012; ISBN 9781622575589.

230. Ahluwalia, R.K.; Wang, X.; Kwon, J.; Rousseau, A.; Kalinoski, J.; James, B.; Marcinkoski, J. Performance and cost of automotive fuel cell systems with ultra-low platinum loadings. J. Power Sources 2011, 196, 4619-4630. [CrossRef]

231. Polymer Fuel Cells-Cost Reduction and Market Potential; Carbon Trust: London, UK, 2012.

232. Wilberforce, T.; Olabi, A.G. Performance prediction of proton exchange membrane fuel cells (PEMFC) using adaptive neuro inference system (ANFIS). Sustainability 2020, 12, 4952. [CrossRef]

233. Rahimi-Esbo, M.; Ranjbar, A.A.; Ramiar, A.; Alizadeh, E.; Aghaee, M. Improving PEM fuel cell performance and effective water removal by using a novel gas flow field. Int. J. Hydrogen Energy 2016, 41, 3023-3037. [CrossRef]

234. Li, Q.; He, R.; Jensen, J.O.; Bjerrum, N.J. PBI-based polymer membranes for high temperature fuel cells-Preparation, characterization and fuel cell demonstration. Fuel Cells 2004, 4, 147-159. [CrossRef]

235. Staffell, I.; Green, R. The cost of domestic fuel cell micro-CHP systems. Int. J. Hydrogen Energy 2013, 38, 1088-1102. [CrossRef]

236. Dyantyi, N.; Parsons, A.; Sita, C.; Pasupathi, S. PEMFC for aeronautic applications: A review on the durability aspects. Open Eng. 2017, 7, 287-302. [CrossRef]

237. Thampan, T.; Shah, D.; Cook, C.; Novoa, J.; Shah, S. Development and evaluation of portable and wearable fuel cells for soldier use. J. Power Sources 2014, 259, 276-281. [CrossRef]

238. Walkowiak-Kulikowska, J.; Wolska, J.; Koroniak, H. Polymers application in proton exchange membranes for fuel cells (PEMFCs). Phys. Sci. Rev. 2017, 2, 1-34. [CrossRef]

239. Ouzounidou, M.; Ipsakis, D.; Voutetakis, S.; Papadopoulou, S.; Seferlis, P. A combined methanol autothermal steam reforming and PEM fuel cell pilot plant unit: Experimental and simulation studies. Energy 2009, 34, 1733-1743. [CrossRef]

240. Martín, A.J.; Hornés, A.; Martínez-Arias, A.; Daza, L. Recent Advances in Fuel Cells for Transport and Stationary Applications. In Renewable Hydrogen Technologies Production, Purification, Storage, Applications and Safety; Gandía, L.M., Arzamendi, G., DiØguez, P.M., Eds.; Elsevier: Amsterdam, The Netherlands, 2013; pp. 361-380, ISBN 9780444563521.

241. Trencher, G.; Edianto, A. Drivers and Barriers to the Adoption of Fuel Cell Passenger Vehicles and Buses in Germany. Energies 2021, 14, 833. [CrossRef]

242. Jourdani, M.; Mounir, H.; El Marjani, A. Compilation of factors affecting durability of proton exchange membrane fuel cell (PEMFC). In Proceedings of the 2014 International Renewable and Sustainable Energy Conference, IRSEC 2014, Ouarzazate, Morocco, 17-19 October 2014; pp. 542-547.

243. Sorlei, I.-S.; Bizon, N.; Thounthong, P.; Varlam, M.; Carcadea, E.; Culcer, M.; Iliescu, M.; Raceanu, M. Fuel Cell Electric Vehicles-A Brief Review of Current Topologies and Energy Management Strategies. Energies 2021, 14, 252. [CrossRef]

244. McLarty, D.; Brouwer, J.; Ainscough, C. Economic analysis of fuel cell installations at commercial buildings including regional pricing and complementary technologies. Energy Build. 2016, 113, 112-122. [CrossRef]

245. Milburn, S.; Adamson, K.-A. The Fuel Cell Stack Supply Chain; Pike Research LLC: Boulder, CO, USA, 2012.

246. Gebert, M.; Höhlein, B.; Stolten, D. Benchmark cost analysis of main PEFC-ionomer membrane solutions. J. Fuel Cell Sci. Technol. 2004, 1, 56-60. [CrossRef] 